\title{
EL LITÓGRAFO LUIS GARCES
}

\section{Por Clementina Diaz y de Ovando}

La litografía, arte romántico por excelencia, invadió todos los campos: literario, histórico, científico. $\mathrm{Y}$ así, las novelas, los folletines se adornaron con la representación ilustrada de aquellas escenas en las que se quería poner más énfasis: la belleza femenina, la emoción que produce el paisaje, los sentimientos, en especial, el amoroso en todos sus matices, las costumbres, escenas en las que el artista interpretaba con libre inspiración al escritor. Para dar una mayor intención a los sentimientos o a las situaciones se acompañaban las litografías de una frase o leyenda alusivas.

Uno de los litógrafos mexicanos que no sólo ilustró obras históricas. sino también novelas, fue Luis Garcés, del que apenas si se tienen datos, pero que merece ser más apreciado por las muy bellas de El libro de Satanás (1869) y las de Un hereje y un musulmán (1869).

Manuel Toussaint en su aportación La litografia en México en el siglo $X I X$, en el apartado "Casas editoriales" dice que después de 1862, el litógrafo de la conocida casa de M. Murguía, establecida en el Portal del Aguila de Oro:

Parece haber sido L. Garcés. Firma en efecto las láminas de Rivera Cambas, México pintoresco (3 vols. 1883) ${ }^{1}$ y Los gobernantes de México (2 vols. 1873). Igualmente Garcés se nos presenta como el

I En el diario La República, de 5 de diciembre de 1880 . Ignacio M. Altamirano en la sección "Bibliografia México pintoresco y artístico por Manuel Rivera Cambas", se refirió a esta obra, "el conocido y laborioso escritor mexicano -dice Altamiranoha comenzado a publicar un libro, que como todos los suyos lleva el sello de la utilidad y de la importancia nacional, lo que se presume desde luego, a juzgar por el título que Ileva.

Faltaba ciertamente una historia de la ciudad de México, una historia que contuviese los datos históricos y artísticos de los edifícios principales y notables... Altamirano tras de elogiar la obra de Rivera Cambas, alaba Ias esmeradas y hermosas estampas, aunque omite cl nombre del litógrafo Luis Garces, y censura a la Escucla de Bellas Artes por no preparar buenos grabadores.

"A su texto: el autor acompaña muy buenas estampas litográficas de los principales monumentos de la ciudad y habría convertídolas en buenos y bellos grabados, si la mentada clase de grabados no fuera inútil por su inferioridad para producir artistas, como los necesitamos.

"Pero las litografias cuidadosamente hechas suplen esta falta y dan muy buena idea de nuestros edificios de México." 
autor de las litografías que adornan el curıoso Libro de Satanás de Adolfo Isaac Alegria, publicado en 1869. ${ }^{2}$

En Mexican litografic tradition, Francisco Diaz de León, muy distinguido grabador, hace mención elogiosa de Garcés, como innovaclor en el tratamiento de los temas:

En el siglo xix mexicano, la litografia se muestra como el aspecto más desarrollado en el arte ... Si usted estudia los trabajos de Constantino Escalante en el periódico La Orquesta o el trabajo completo de Hesiquio Iriarte, o la particular fina observación de la litografía de Garcés, estará capacitado, entonces, para valuar la técnica litográfica mexicana en el siglo xix... Atonino y Anita o los nuevos misterios de México presenta la fragilidad de preciosas y sentimentales composiciones de los siglos anteriores. Y hasta 1869 la litografía mexicana continúa produciendo ese tipo de cuadros. Entonces vino Garcés, El libro de Satanás - algo que parece ficción y no lo es-creencias, claroscuro, tristeza, felicidad y melancolía. Pero aquí las ilustraciones van más allá de los límites de la elocuente historia. ${ }^{3}$

Otra referencia también lisonjera a Garcés y al Libro de Satanás se encuentra en el artículo del pintor Fernando Leal, "La litografía mexicana en el siglo xıx", publicada en Artes de México. Leal reproduce, como Toussaint en su ya citada monografia la estampa "Hay chic..." y alaba su gracia, su ironia, su composición:

2 Ediciones facsimitares de la Biblioteca Nacional de México. (UNAM) Estudios Neolitho. M. Quesada. México 1934, p. xix. Se publicó con motivo del cincuentenario de la Biblioteca Nacional de México, 2 de abril de 1884 . En este volumen se repro. lucen "sesenta facsimiles de las obras". En "Una antología litográfica", Antonio Acevedo Escobedo, comentó encomiásticamente "La litografía en México" (Revista de Revistas, México, 6 de mayo de 1934).

3 Mexican Art and Life. México, DAPP, No 3 , julio de 1938.

Francisco de la Maza en Revista de Bellas Artes número 23, scptiembre-octubre de 1968. INBA, hizo un apretacto, ameno, interesantísimo estudio: "La novela. Los nuelos místerios de México y sus litografías", de las ilustraciones de Casimiro Castro tomadas de los dibujos de Eduardo Rivière, quien escribió $\mathrm{y}$, a la vez, realizó los dibujos de la novela Antonino y Anita o los nuevos misterios de México, 1851, "Novela religiosa y moral, escrita en francés en csta capital por E. Rivièe, e ilustrada por él mismo con hermosos dibujos." "La novela -afirma de la Maza- vale por los dibujos de Rivière", excelente artista, fino observador de los valores plásticos del arte novo. hispano, único que había para 1851 , antes de la destrucción vandálica de la arquitectura civil y de la también atroz, pero más justificable de los conventos. Su puesto entre los artistas del siglo $\mathrm{x} I \mathrm{x}$ en México debe ser conocido y valorado... Y, desde luego, por las litografias de Casimiro Castro, que parece son las primeras obras conocidas de Castro:" 
El libro de Satanas, curiosa novela de Adolfo Isaac Alegria, contiene varias láminas del mismo autor [Luis Garcés], que se distinguen por la sutileza de valores y por las delicadas calidades que el artista ha conseguido sobre la piedra. Especialmente, quiero recordar una, en que aparece una apetecible jamona, ataviada con la atrabiliaria profusión de randas olanes y abullonados que transforman el cuerpo femenino en una verdadera abstracción caprichosa. Hasta los más minimos detalles de la graciosa composición, parecen haber sido agrupados expresamente para producir un contraste divertido con la leyen. da "Hay chic..." que le sirve de pie."

Justino Fermándex, en $k l$ arle en el siglo $\mathrm{X} I \mathrm{X}$ en México, afirma:

La literatura romántica daba ocasión para que los litógrafos se lucieran y desde las portadas hasta la ilustración de las escenas particulares, el ingenio de los artistas se produce, ya dulce, melancólico o irónicamente, como en El libro de Satanás (1869)."

Gracias a la gentileza del crítico literario José Luis Martínez, el más conocedor de la literatura mexicana del siglo $\mathrm{xIx}$, me ha sido posible conocer $E l$ libro de Salanás y reproducir aquí las litografías que son las que dan interés y valor a esta publicación. Aigunas están firmadas por Luis Garcés, otras no llevan firma, pero es indudable que son de este litógrafo, todas llevan al pie: "Litografía de la viuda de Murguía e hijos". Hago patente mi reconocimiento a José Luis Martínez.

El libro de Satanás del escritor y periodista político Adolfo Isaac Alegría, conocido por su seudónino "Satanás", consta de dos partes, la primera publicada en 1869 lleva en su portada este extravagante título: El libro de Satanás. Algo que parece nonela y no lo os. V'erdades clates y oscuras, tristes alegres y lígubres. Sacadas de los archivos del inficmo. México. Imprenta de la Constitución social. 1869. La segunda parte se titula: La luz en las tinieblas. Novela filosófica y de costumbres. México. Imprenta de Tomás E. Neve. Santa Clara y Cinco de Mayo. 1870 .

La primera parte de El libro de Satanás está dedicado por el editor, doctor Vicente Licea "en prueba de gratitud, respeto y amistad, al dis-

4 México, vol. III, año Iv, núm. 14 .

:Universidad Nacional Autónoma de México, Instituto de Investigaciones Fstéticas. México, 1967, p. 127. 
tinguido jurisconsulto" Manuel Romero Rubio, importante político en aquellos años. Esta primera parte va antecedida de unas palabras del editor que son, en realidad, un desahogo en contra de la doctrina positiva que ha propiciado la entrega de la sociedad "a la especulación, al cálculo y a satisfacer sus intereses materiales y las más innobles pasiones, la indiferencia y el egolsmo..." "la sociedad descarriada de su camino ha dado un paso hacia atrás marchando por la senda del positivismo". De manera que las puertas quedan abiertas a los vicios, a las malas acciones que se disfrazan con la capa de la virtud. La sociedad al perder sus ilusiones por culpa del positivismo, ha dejado de elevarse "a las regiones de lo desconocido y de lo infinito en donde buscaba la solución de los problemas que no le era dado comprender" y se ha rendido de lleno a la satisfacción de los sentidos. Licea censura la ordenación del mundo progresista del positivismo, pues ha llevado a la humanidad a encontrar distracción en el ruido del vapor, a asombrarse con la electricidad, abandonando los goces espirituales y descuidando la enseñanza del espíritu:

El libro de Alegría -sentencia Licea- despoja a la humanidad de ese falso traje y le arranca la máscara para hacerla ver como ella es y no como quiere ser... Su fecunda pluma llena de meditación y filosofía, ha estampado en el curso de su obra estas notables cuanto significativas palabras: "El materialismo y la falta de fe para el porvenir, son el mayor estímulo que tiene la humanidad para cometer sus locuras."

De aqui el gran beneficio, según Licea, que Alegría hace a la sociedad al demostrar el engaño de ese materialismo que embota el espíritu. Licea, por tal motivo, se enorgullece de contribuir a esa propaganda contra el materialismo imperante al editar El libro de Satanás, obra escrita en un "lenguaje que encanta por su naturalidad, fluidez y armonía sin carecer de elegancia y sencillez".

Alegría, revolviendo el infierno cristiano con la mitologia griega inicia su obra con este párrafo:

Yo, Satanás, rey y soberano de los Infiernos, certifico, y doy fe que la presente obra, está sacada fiel y conforme a los datos que existen en los archivos y notas de estos mis dominios.

Otro sí: nunca, sino hasta ahora, se ha permitido ver a los profanos tales documentos.

$\mathrm{Y}$ para que conste, extiendo el presente certificado en la Laguna 
Estigia a los 28 días del mes de octubre de 1869 , y a los 7066 de nuestro reinado.

El autor sostiene, a seguidas, que su libro no tiene intención de herir a nadie sino apoyarse sólo en la vulgar ley que llama al pan, pan, y al vino, vino, y para descargo de su conciencia liberal abjura de los "errores que se encuentren contra cualesquiera de las religiones, sectas, cultos, etcétera, que en el globo se profesen".

Entrando en materia, Alegría reflexiona sobre el amor, Ia esperanza, el remordimiento, la guerra, la política, la caridad, la gloria, el chic, la mujer, la moda, el tiempo. En su libro no aparece por ningún lado la filosofía $y$, aunque tiene sus lecturas y alguna erudición, sus pensamientos con pretensiones de lección moralizante, están expuestos con una gran sencillez, sin la penetración y el aliento necesarios para cumplir el cometido que su editor y él se han señalado: la crítica al positivismo.

Gabino Barreda, el adalid de esta filosofía en México, y sus seguidores deben haber pensado que, con requisitorias como esa, el positivismo impuesto como doctrina oficial en la Escuela Nacional Preparatoria (Ley de 2 de diciembre de 1867), no tenía nada que temer. Sin embargo, ante el recelo de que la clase media que era la que leía novelas pudiera captar el mensaje de Alegría subrayado por el litógrafo Garcés, el director del Diario Oficial, Dario Balandrano se apresuró a desaprobar $E l$ libro de Satanás, tomando en cuenta también que el positivismo era la filosoffa auspiciada por el gobierno, dejó muy maltrecho por ser mala literatura y peor filosofía al Libro de Satanas.

En su conjunto esta obra carece de valor literario, su interés, huelga decirlo, lo constituyen las litografias de Luis Garcés, que con gran acierto no sólo interpretó el reproche de Alegría al positivismo remachando los ideales románticos, sin $\rho$ también, otorgó a esas ingenuas y manidas reflexiones la belleza, la categoría artística y esa hondura metafísica que el autor, pese a su intención no alcanzó. En otras litografías, Garcés nos deja una magnífica pintura del ambiente de los interiores de las casas y de los edificios hoy, por desgracia, desaparecidos, así como de las costumbres.

Se rebela contra la moda imperante, pues se come, se bebe, se fuma. se viste, se duerme y hasta se muere a la francesa, moda que es muy natural que se desapruebe, ya que México acababa de triunfar sobre la intervención francesa y el imperio de Maximiliano de Habsburgo (1867) 
$y$, por lo mismo, tenia que hacerse hincapié en la.vuelta a las desdeñadas costumbres mexicanas, como uno de los medios de afirmación nacional.

Un excelente retrato de Alegría, va en la segunda falsa. No cabe duda que el escritor "Satanás" era un hombre bien parecido. De líneas muy finas esta litografía anuncia ya al retratista de Los gobernantes de Mćxico (figura A).

El orden de las litografías es como sigue:

1. Esta primera litografía lleva como título: "El libro de Satanás."

La leyenda está recortada no se lee. Satanás está representado a la manera medieval, un detalle curioso es que en vez de la pata de cabra ostenta una pata de gallo con espolón. Con disciplina prepara las notas y documentos de su archivo personal. Satanás se apoya en la muerte, a sus pies se encuentra la serpiente, otra de sus imágenes, aquí el símbolo del pecado y de la discordia. Un libro abierto con el nombre de los siete pecados capitales - sobre los que Alegria especula- se recarga en la mesa. No faltan el fuego, los rayos y los esqueletos de trazo muy suave, y el tiempo: la clepsidra.

2. Con la sentencia que aparece al pie de la litografía tomada de el Génesis Ir. 23 y 24: "Por el cual [el amor] dejará el hombre a su padre y a su madre y se unirá a su mujer y serán una sola carne."

Alegría desclobla las diferentes clases del amor: de padre, de hijo, de hermano, de amigo, a la patria, los que se aman a sí mismos. Y el amor de los amantes, dulce beleño con sus deleitosos inicios, el acíbar del desencanto y su fin casi siempre desastrado.

Garcés ilustra estas ideas con una tierna escena bucólica. Dos adolescentes pastorcillos abrazados se solazan con la música del caramillo, el perro - la fidelidad- está a un lado, atrás unas cabrillas retozan, la mansedumbre de un cordero da a la escena una mayor placidez, unas avecillas se besan en el alero de una casa de estilo europeo. El paisaje romántico: montes de suaves laderas, arroyuelo de aguas mansas, verdura y árboles. Este paisaje realizado con oficio da relieve a la emoción misteriosa del amor.

3. "Todos ioh gloria!, con afán te siguen."

Acicate que mueve al hombre. Fascinados por la gloria, sin percatarse -afirma Alegria- de su ligereza, de su complacencia en jugar y burlar los deseos la persiguen el filósofo, el pintor, el músico, el sabio, el guerrero, el matemático, el rico. 
El artista va más allá del pensamiento de Alegría, la voluntad de gloria, tormento y apetencia del romántico la expone en esta estampa de manera estupenda. Representa a la gloria como una doncella hermosa y etérea inalcanzable, huidiza. Una estrella suspendida le sirve de diadema y, a la vez, la ilumina. La gloria retiene y no parece dispuesta a soltar la corona de laurel que anhelan ceñirse los que la acosan: el escultor, el arquitecto, el músico, el poeta, el pintor, es decir, las artes mayores, detrás de éstas va el guerrero al que acompaña una matrona -acaso la riqueza- que lleva un puñal; la violencia y una máscara: el engaño, armas de las que se vale el guerrero para asir la gloria. Después de éste y la matrona suntuosamente vestida viene el sabio, como un viejo poseedor de los méritos de la experiencia. En su afán de alcanzar la gloria todos abandonan el oasis, la victoria de la paz del alma, simbolizada por la palmera y, en esa su vehemencia de posteridad sólo llegan al desolado paraje piedras y ramas secas del silencio y del olvido.

La túnica de la gloria y su manto, así como el "quitón" corto de las artes tienen la tersura y la transparencia propias del gusto romántico. La sencillez de la composición, escasamente una diagonal, marcada por el cuerpo de la gloria, da idea de una cauda que parte de la estrella que atrae a los ansiosos de la fama.

4. "Entre miradas y suspiros aparece la luna de miel."

Alegría, recordando a Mariano José de Larra, que usó entre otros seudónimos el de "El Pobrecito Hablador", dice que cualquiera tema es útil al hablador que es el escritor o el periodista, y escoge como motivo la luna de miel. Dfas venturosos, plenos de ilusiones, de halagos y caricias que transcurren entre miradas, suspiros, sonrisas, juramentos, estado transitorio de embeleso, roto cuando menos se espera por la realidad, entonces la luna de miel se torna eclipse total: decepción, indiferencia, amargura.

Garcés interpreta románticamente la luna de miel: un claro mediodía en un jardín, con su fuentecilla al fondo, las nubes sugeridas tamizan la luz. Los enamorados inmersos en el abandono de su dicha, cuyo embeleso expresan sus ojos, no advierten la maliciosa sonrisa del amorcillo que, desde su pedestal, parece preguntarse ¿cuánto durará a estos lunamieleros el suspirar y el mirarse?

Las figuras dibujadas cuidadosamente delatan la moda del tiempo: el peinado, la sombrilla, las manos enguantadas y dentro de lo esquemá- 
tico de los ropajes: la discreta crinolina, la capa, el ajustado pantalón y el surtout.

5. "¿Quién es ante Dios el mayor y el más santo? - El que tiene mayor caridad, sea quien fuere. Ripalda."

La exaltación de la caridad - que muy pocos practican- es el tema que ilustra Garcés. Lo interesante de esta litografía es la pintura de un establecimiento de la caridad. La arquitectura enseña una especie de portería de un orfanatorio, en la parte alta se encuentra un cuadro de la caridad y, abajo, en el torno, un niño depositado para ser recogido, un limosnero entra en el recinto. La cratícula se distingue en la hoja de la puerta. El orfanatorio pertenece a las hermanas de la caridad, en el arco de la entrada está inscrito el nombre de San Vicente de Paul. No es casualidad que el artista haya anotado el título de esta institución, su idea fue recalcar su encargo caritativo, pues en esos dias por haber sido protegida por la emperatriz Carlota estaba en entredicho, en la prensa periódica se le atacaba, se le defendia. Las hermanas de la caridad fueron expulsadas por decreto de 30 de noviembre de 1874, durante el gobierno del presidente Lerdo de Tejada. La portería que dibujó Garcés, posiblemente sea la del convento de las hermanas de la caridad, situado frente a la plaza de Villamil, hoy Aquiles Serdán.

6. "El honor y la virtud de una esposa exigen una satisfacción cuando se han violado."

La larga disertación de Alegría sobre la virtud que, unas veces es hipocresía, y otras, se confunde con el honor, Garcés la sintetiza en este acontecimiento del vivir cotidiano: el adulterio sorprendido que pide una satisfacción, esto es, un duelo.

El escenario es una habitación de una casa de gente adinerada en todos sus detalles, las paredes con estucos, la cama con rico dosel de damascos y crespones, el espejo de ángulos redondeados y foliaciones aplicadas. Las figuras -otra vez muy bien dibujadas- los hombres vestidos como dandys, revelan en su rostro lo sucedido: la cólera del esposo que ha derribado una silla y con el dedo muestra la exigencia por reparar su honor. El susto del amante -l pelo y el bigote se le han puesto de punta-, todavía aprieta en su mano una rosa, en el lenguaje de las flores, amor voluptuoso. La apesarada mujer, en su soponcio saca su pequeño pie calzado con primoroso botín. Garcés puso énfasis en el "piececito mexicano" que tanto impresionó al poeta español 
José Zorrilla y elogió Guillermo Prieto. Alegría por su parte, menciona "los breves y diminutos pies calzados con todo el chic que caracteriza a nuestras elegantes mexicanas". La escena ironiza la virtud hipócrita y el exagerado sentimiento del honor.

7. "Hay chic..."

Alegria en este apartado pretende definir lo que es el chic palabra francesa usada a diestra y siniestra por los extranjerizantes y que, en resumidas cuentas es el "aquello", el "no se qué" español. El chic "el aquello -es para Alegría- lo que nos encanta, lo que nos fascina, lo que causa efecto, lo que nos seduce".

Garcés encontró que "Hay chic..." en esta robusta mujer, vestida con ostentoso y sobrecargado traje para baile. Sobre la crinolina, una primera falda a cuadros, otra segunda falda o túnica de seda lisa con un olán o festón. La moda que reseñaban desde Madrid Pilar Sinués de Marco en "Revista de modas" y en México, Enrique Chávarri, "Juvenal" en "Charla de los domingos", " reclamaba como una novedad "cara y extraña" flores naturales en la falda, y una en cada manga tal como se aprecia en la litografía, el artista adornó aún más la manga al ponerle moño y encajes. La diadema que debía llevarse en el peinado de baile que está de acuerdo la época, la ha sustituido Garcés por un pequeño ramillete de pedrería que se seguía usando.

Esta mujer tan chic luce un precioso broche en el cinturón, una ancha pulsera, lindos aretes y un anillo en el dedo meñique. Sus pies pequeños están calzados con botines de razo de seda y apoya las puntas en cojín de terciopelo, deja ver un pedacito de sus fuertes piernas. Recargada en una mesita con quinqué y florero y cuyas molduras se resaltan, está ensimismada pensando en lo que dice la carta que sostiene en la mano. La cortina y el gran espejo con marco dorado completan el precioso cuadro.

Esta litografía por su gran encanto y gracia cautivó a Toussaint y, como una de las más representativas de Garcés, la incluyó entre los sesenta facsímiles que figuran en La litografia mexicana, ya mencionada, también enamoró a Fernando Leal que la reprodujo en Artes de México.

8. "Es la mujer del hombre lo más bueno -es la mujer del hombre lo más malo." Estas líneas iniciales de un soneto de Lope de Vega que

6 La "Revista de modas" y la "Charla de los domingos" se publicaban en el perio do El Monitor Republicano (1869). 
considera a la mujer "espada de dos filos", definición con la que Alegría no está de acuerdo, pues la refuta con una apasionada loa a la mujer. Cita a las eminentes mujeres que en el mundo han sido y repasa lo que el hombre debe a la mujer. Tan brioso enaltecimiento -con. fiesa Alegria - se lo ha enviado desde los infiernos Satanás, concretándose a copiarlo. La mujer es ángel y demonio para los románticos, la exaltan o la niegan. Satanás, por lo visto, se ha vuelto un romántico y se inclina por la mujer-ángel, según lo demuestra en el endiosamiento e idolatría de sus párrafos.

La mujer-ángel, Garcés la dibuja como una ninfa que se cubre con velo vaporoso y transparente que, sin embargo, permite ver la belleza y gracilidad de sus formas, lo que no deja de ser un atrevimiento y un adelanto para su época. El desnudo femenino no era tema de nuestra pintura. La cazadora de los Andes de Felipe Gutiérrez es el único desnudo femenino de la pintura académica mexicana, que figuró en la vigésima segunda Exposición Nacional de Obras de Bellas Artes, 1891.

El poético paisaje con el agua, las rosas, las insinuadas frondas evocan esas leyendas de Gustavo Adolfo Bécquer de mujeres fantásticas que emergen del lago como en "Los ojos verdes" o se deslizan en "El rayo de luna".

9. "Por ti tan sólo Guadalupe hermosa -pulso las cuerdas de mi tosca lira."

A los ardientes versos dedicados a Guadalupe responde este exquisito retrato en el que se destacan los adornos del traje y los plisados de las escarolas de la blusa. El empaque, el peinado y hasta el rostro de frente $y$ el busto en ligero escorzo traen a la memoria los retratos de la emperatriz Carlota, tal el de Santiago Rebull, y el grabado de Hesiquio Iriarte publicado en México y que circuló como hoja suelta.

10. "Todo vive, todo crece, y todo muere con el tiempo."

"Satanás" se desborda al hablar del tiempo ya como clima, como riqueza para el que trabaja, bendición para el que nace y llega a tiempo, el que todo lo cura, que a todos iguala como la muerte, y todo lo destruye.

En una admirable y metafísica alegoria del tiempo, Garcés recoge la meditación del autor. Un triste paisaje al que ilumina el sol al ocultarse. Al fondo un templo de la región poblana, que el artista debió haber conocido y recrea, muestra en la fachada una de las últimas fases del barroco: las dos pilastras que se componen a base 
DOI: http://dx.doi.org/10.22201/iie.18703062e.1976.45.1031

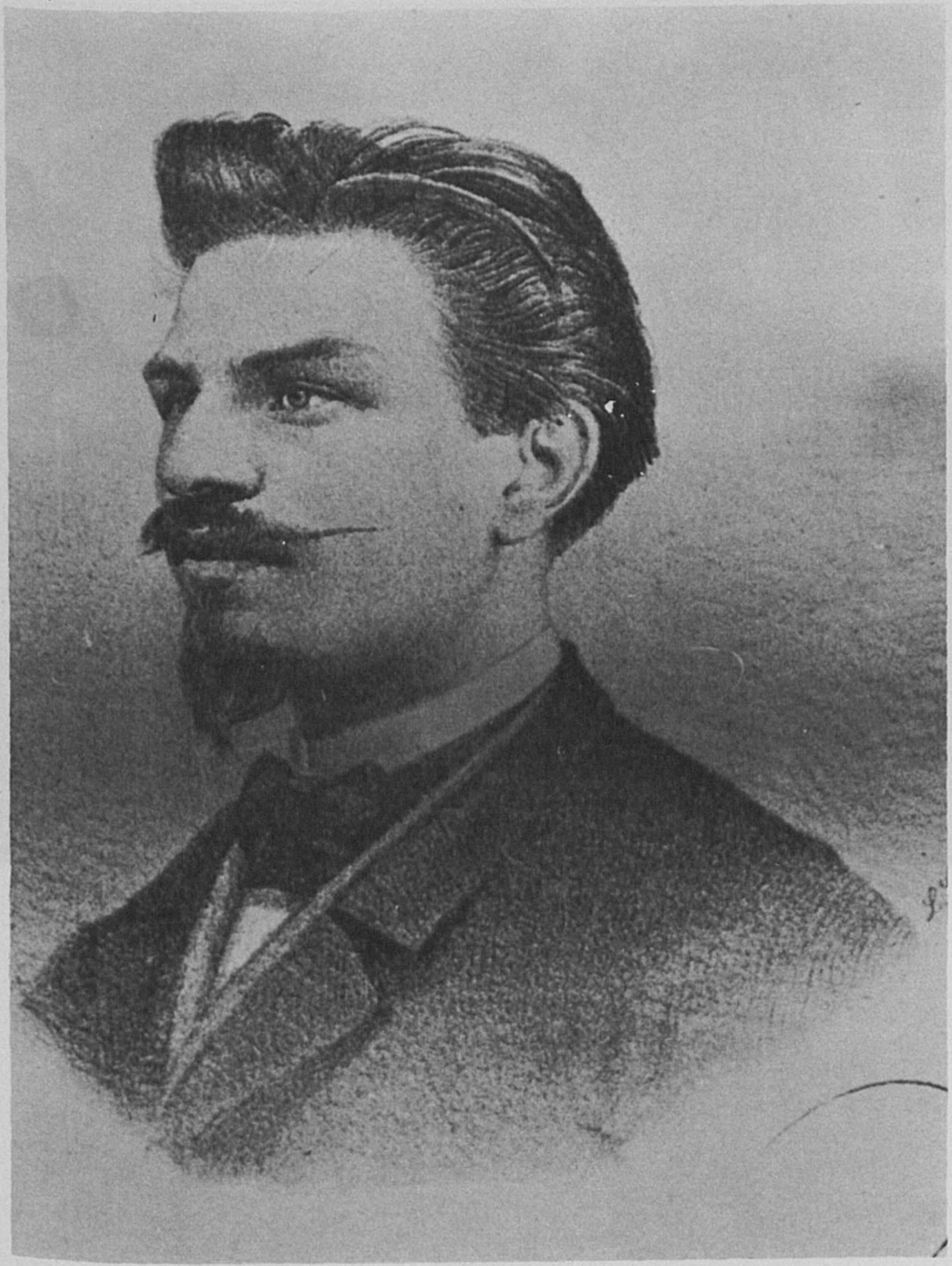

A. Retrato de Adolfo Isaac Alegría (El libro de Satanás). 
DOI: http://dx.doi.org/10.22201/iie.18703062e.1976.45.1031

Q) Libro de Satanás.

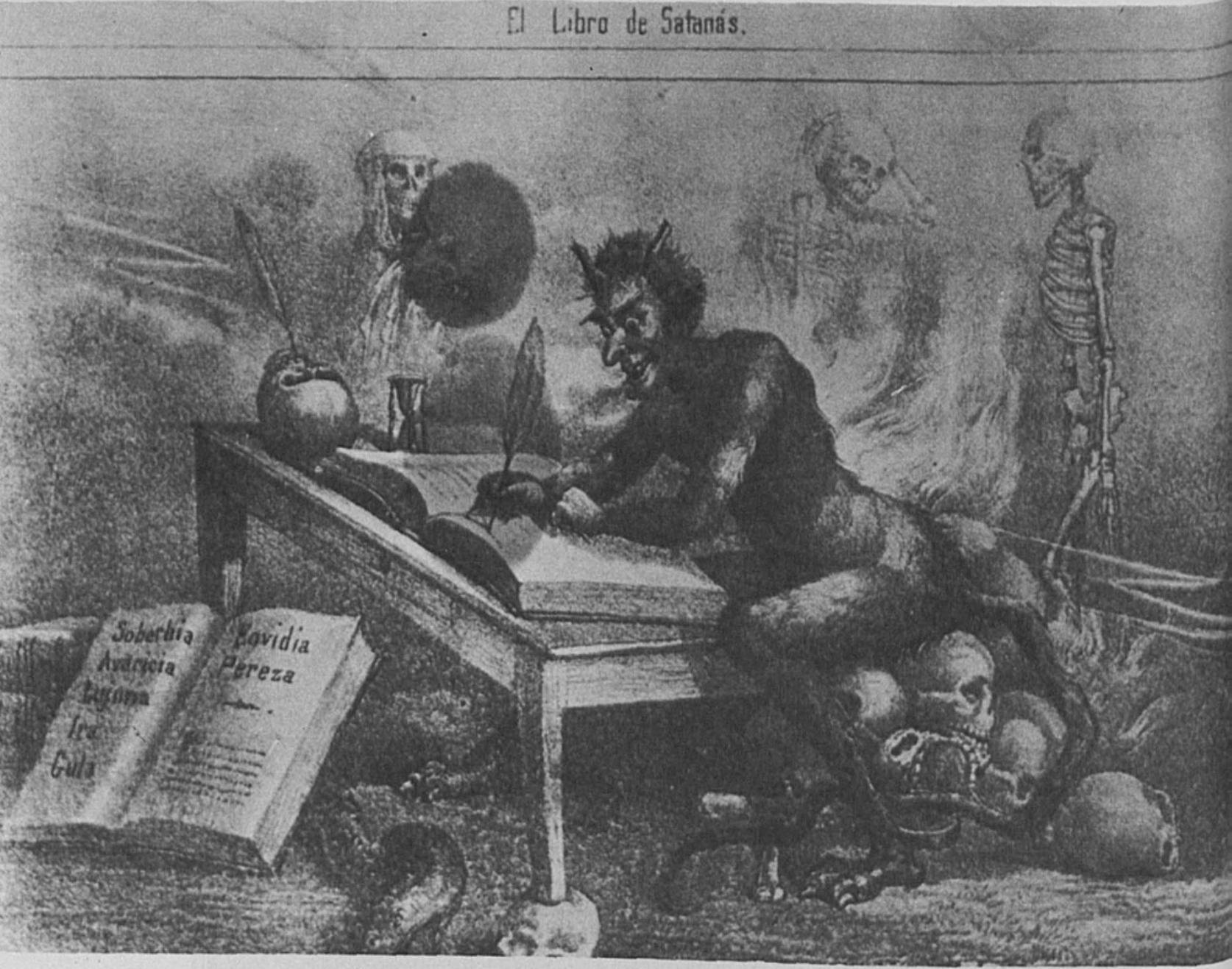

\section{El libro de Satanás.}


DOI: http://dx.doi.org/10.22201/iie.18703062e.1976.45.1031

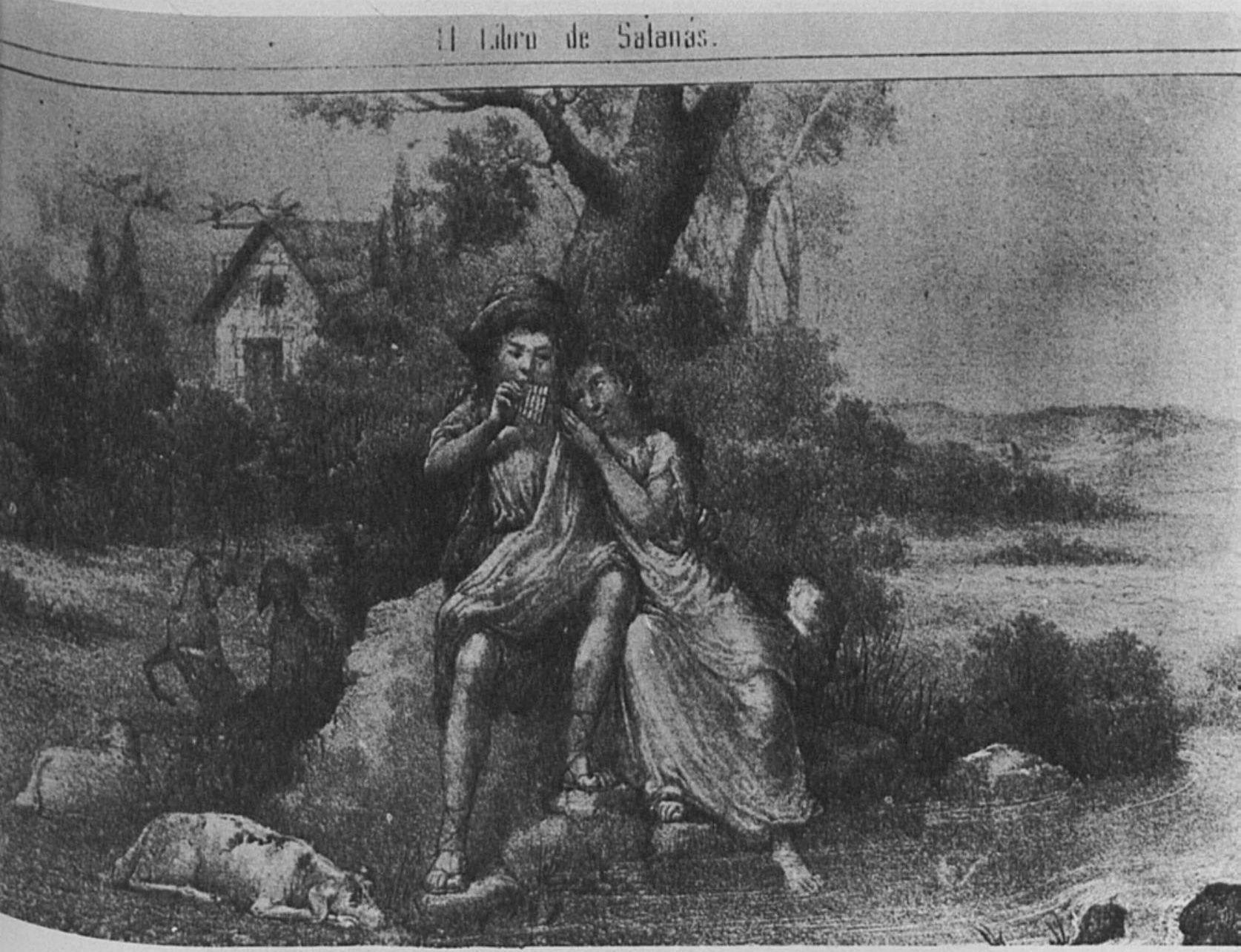

2. Por el amor dejará el hombre a su padre y a su madre... El libro de Satanás. 
DOI: http://dx.doi.org/10.22201/iie.18703062e.1976.45.1031

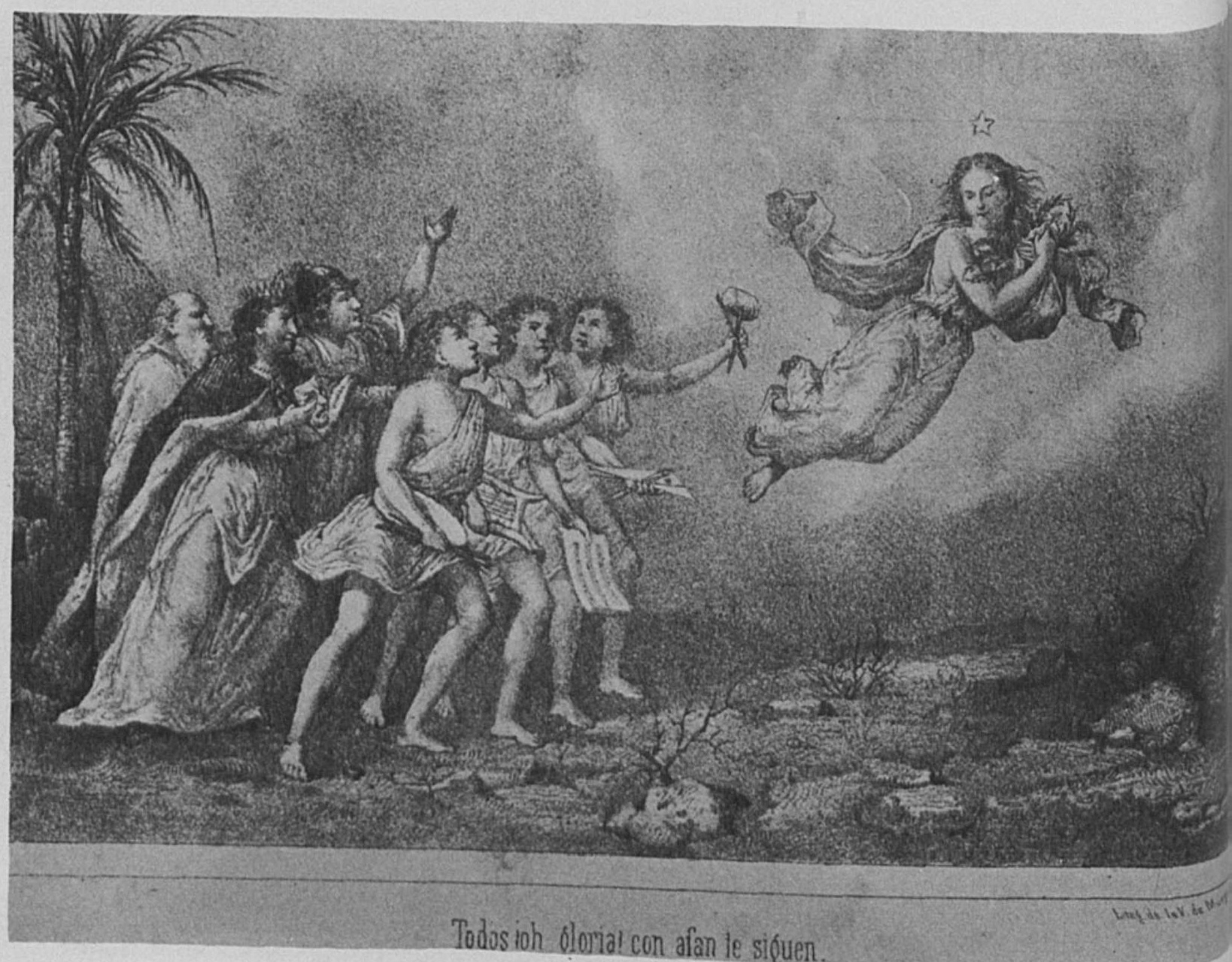

3. Todos ioh!, gloria con afán te siguen (El libro de Satanás). 


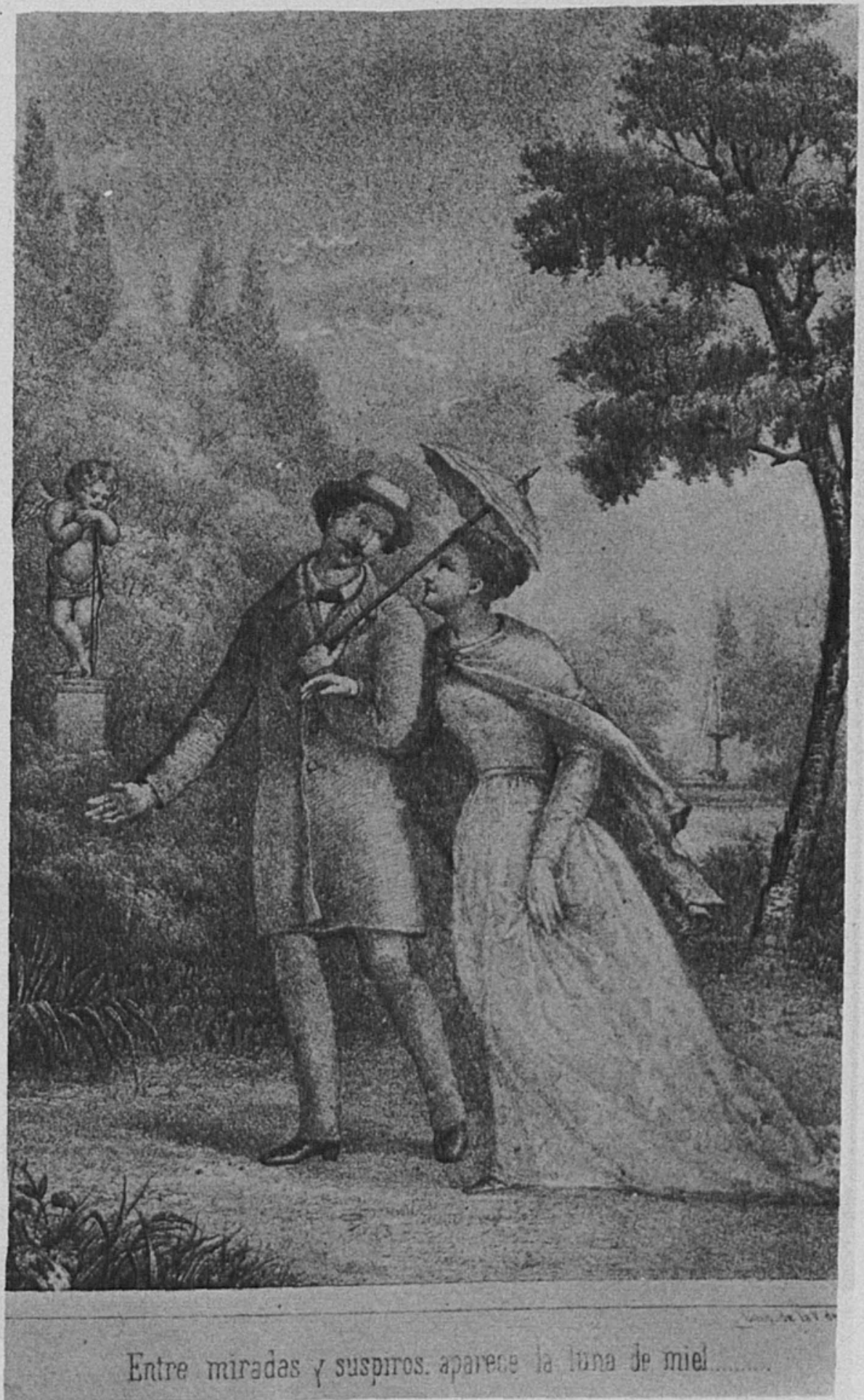

4. Entre miradas y suspiros aparece la luna de miel (El libro de Satanás). 
DOI: http://dx.doi.org/10.22201/iie.18703062e.1976.45.1031

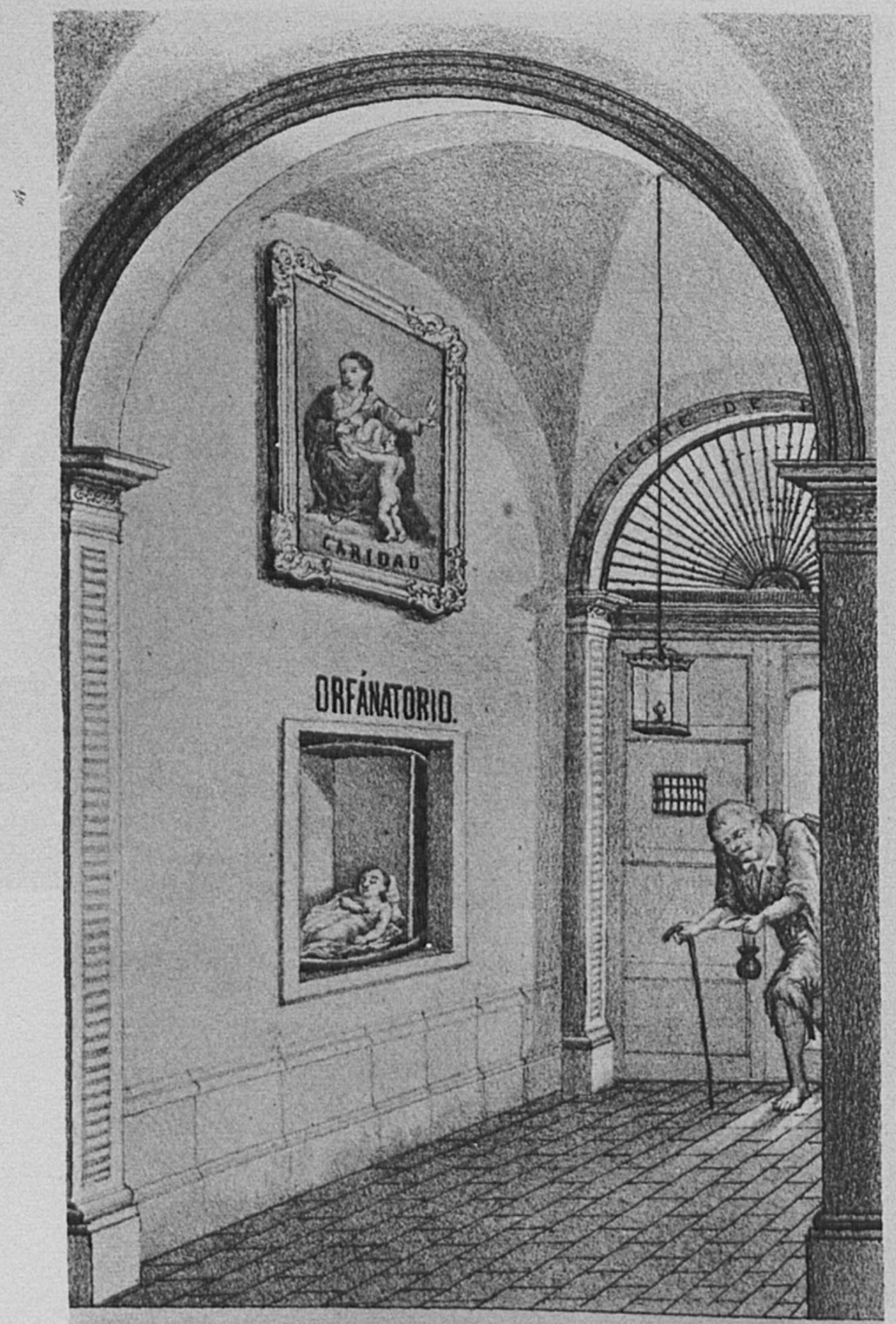

- ¿Qivien es ante Dias cl mayor y rass santo?

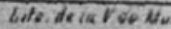

- Ei que tiene mayar caridad,ser quienfuere. . . ...

5. ¿Quién es ante Dios el mayor y el más santo? ... (El libro de Satanás). 


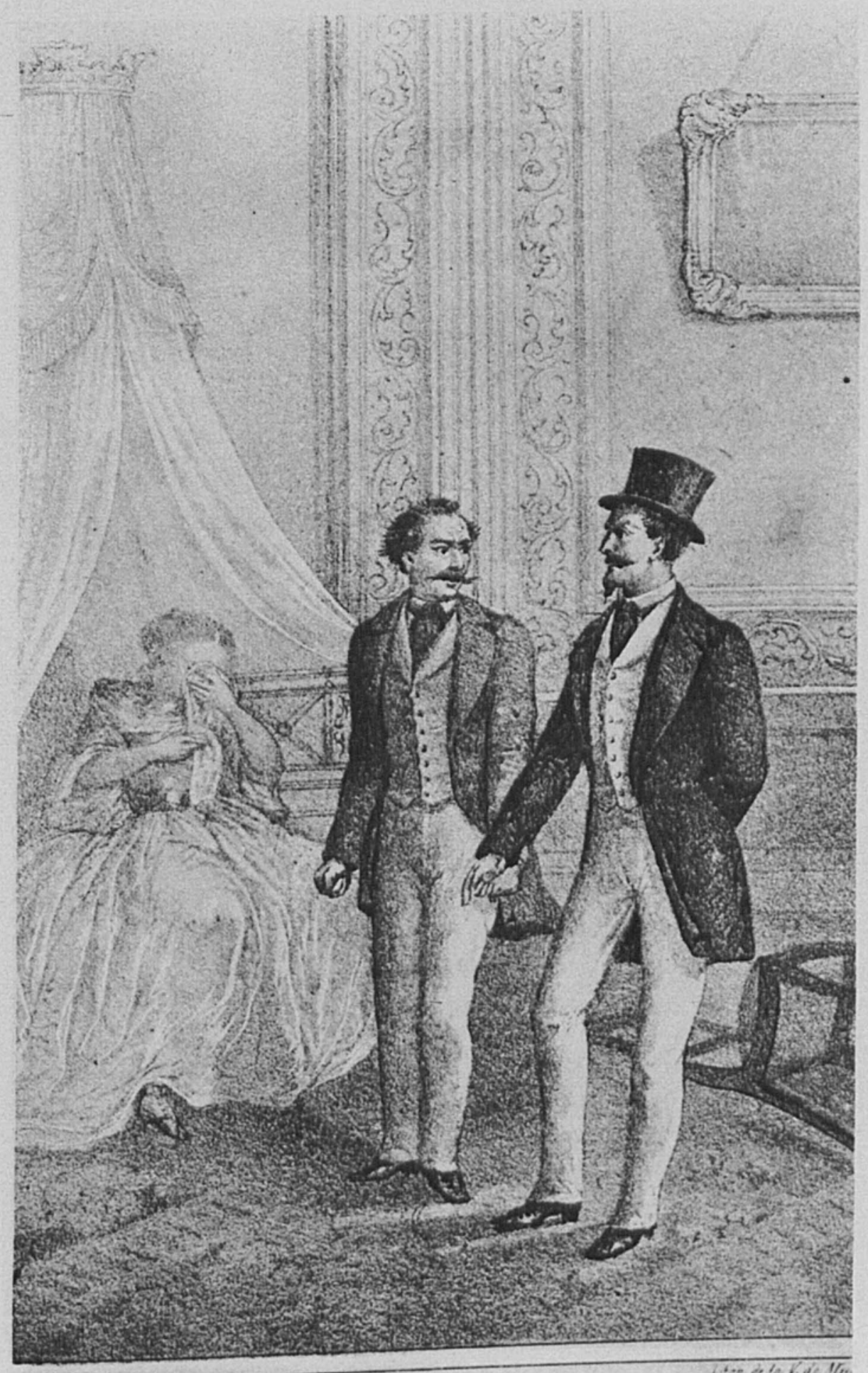

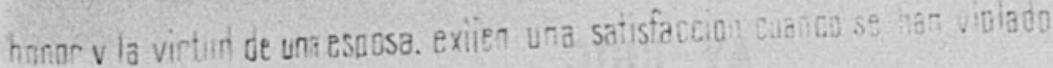

6. El honor y la virtud de una esposa exigen una satisfacción cuando se han violado (El libro de Satanás). 
DOI: http://dx.doi.org/10.22201/iie.18703062e.1976.45.1031

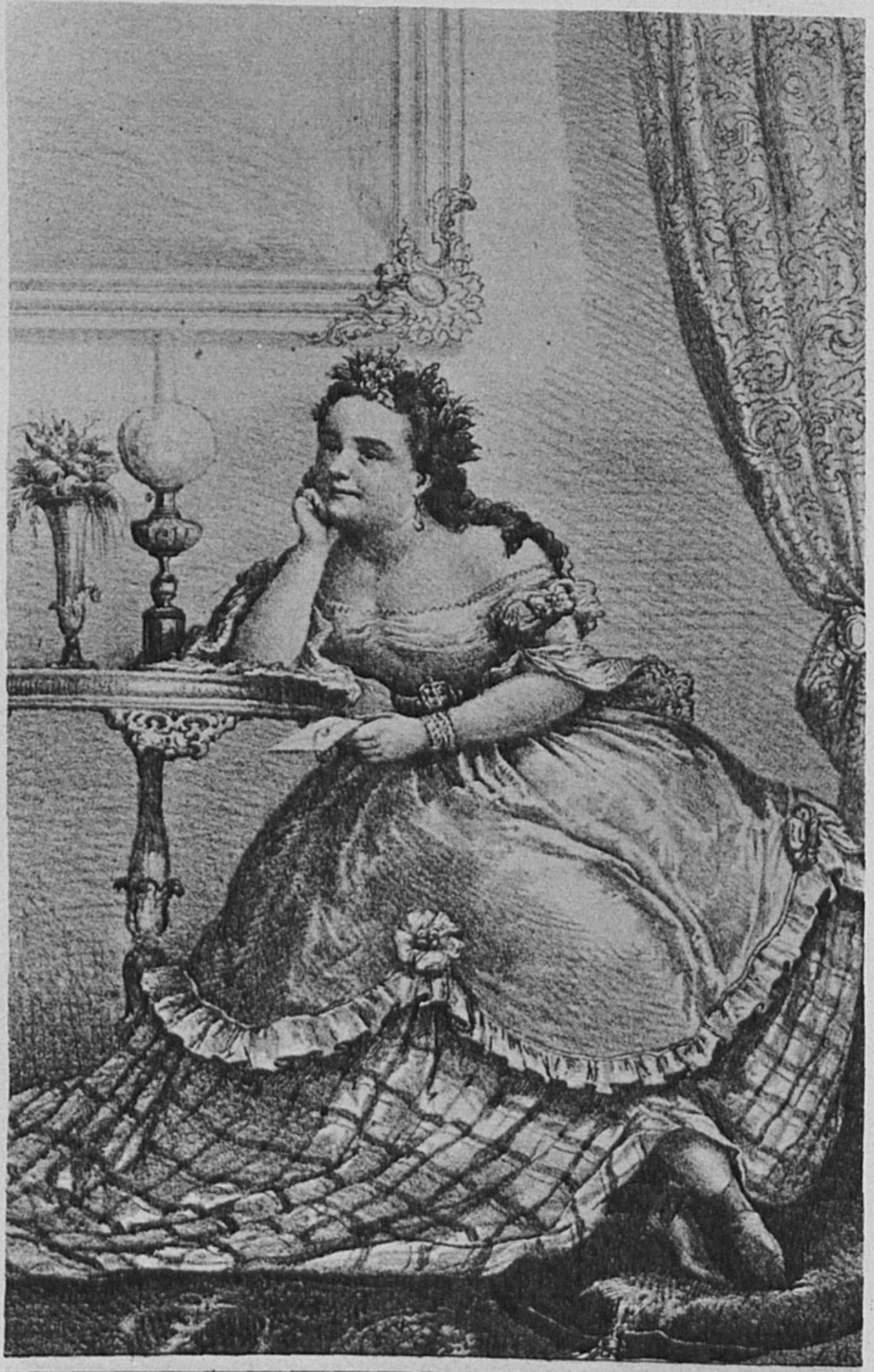

bitey do la kita sturguisa

\section{AY CHIC......}




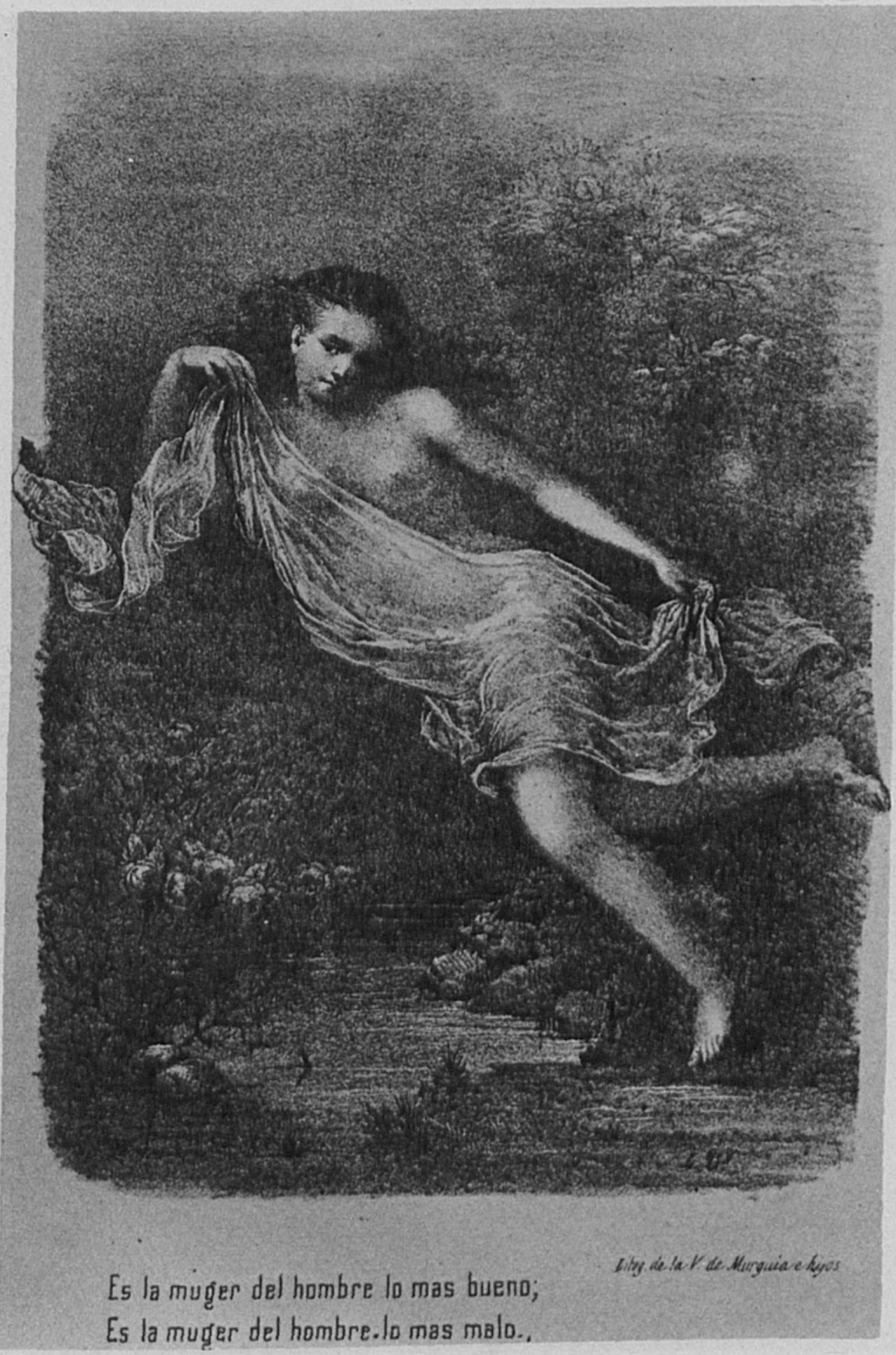

8. Es la mujer del hombre lo más bueno -es la mujer del hombre lo más malo- (El libro de Satanás). 


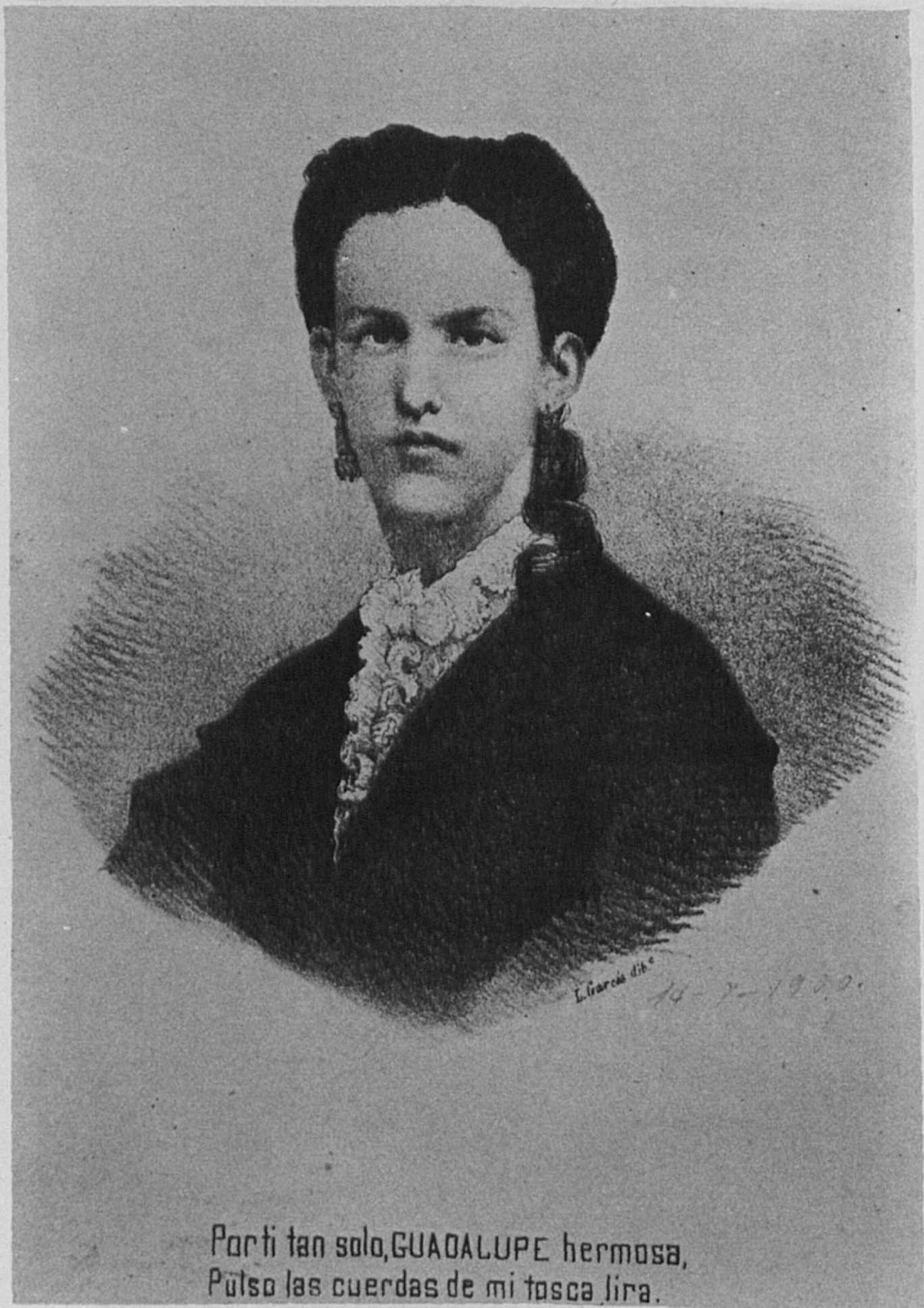

9. Por ti tan sólo Guadalupe hermosa pulso las cuerdas de mi tosca lira (El libro de Satanás). 


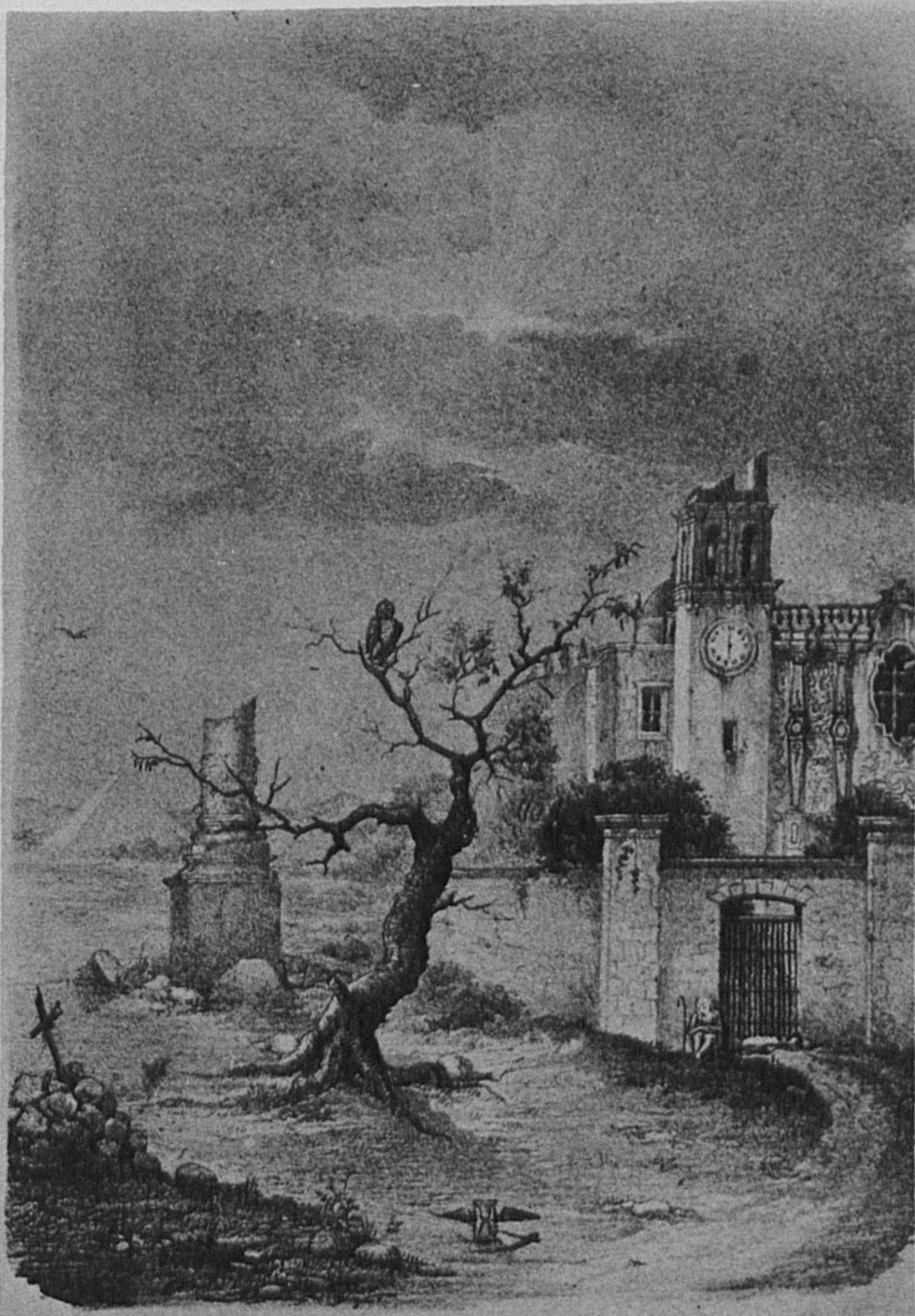

lity delardertongora.

Tado vive, toda crece, y todo muere can el tiempo.

10. Todo vive, todo crece y todo muere con el tiempo (El libro de Satanás). 


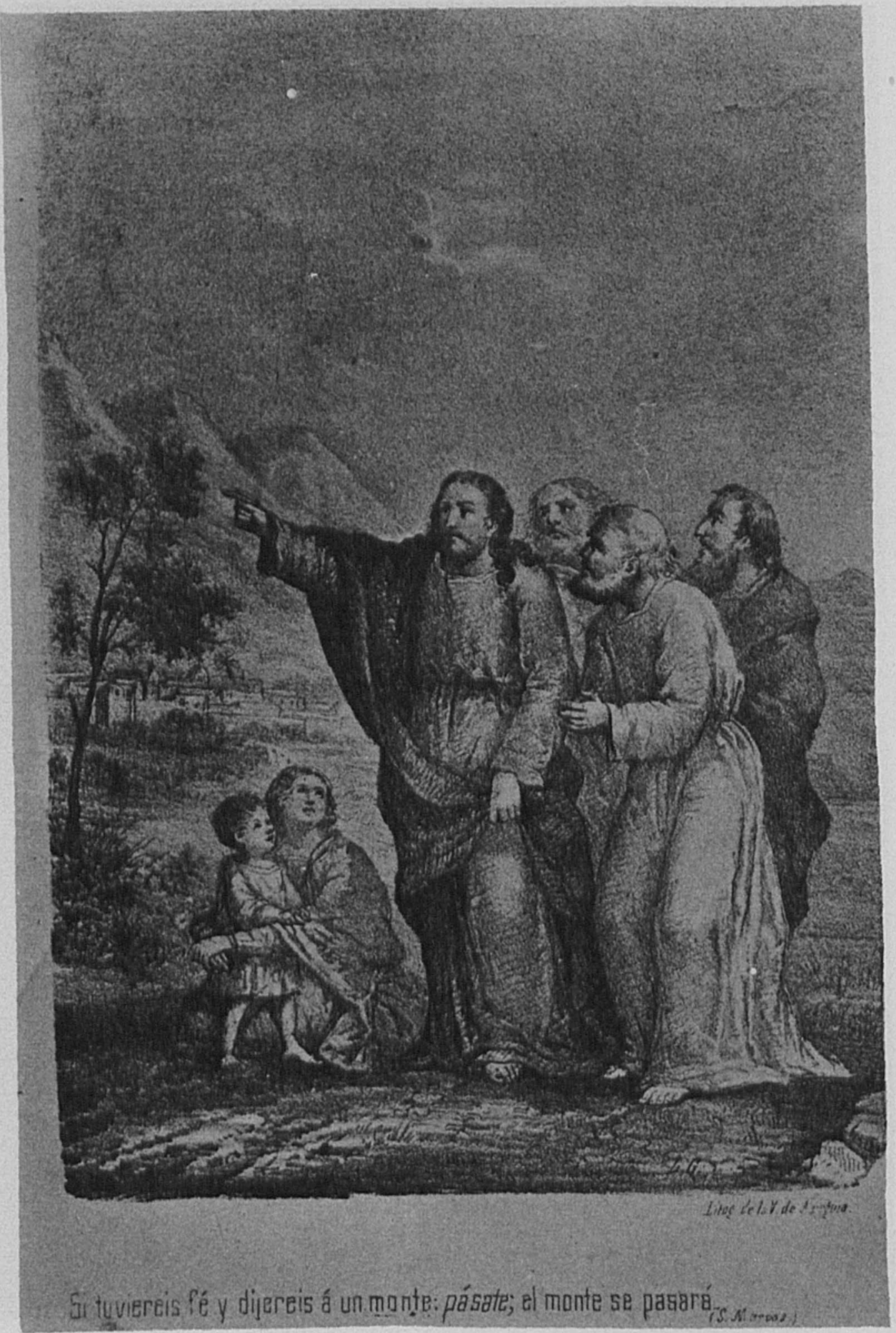

11. La fe. Si tuviereis fe dijereis a un monte: pásate; el monte se pasará (San Marcos) (El libro de Satanás). 


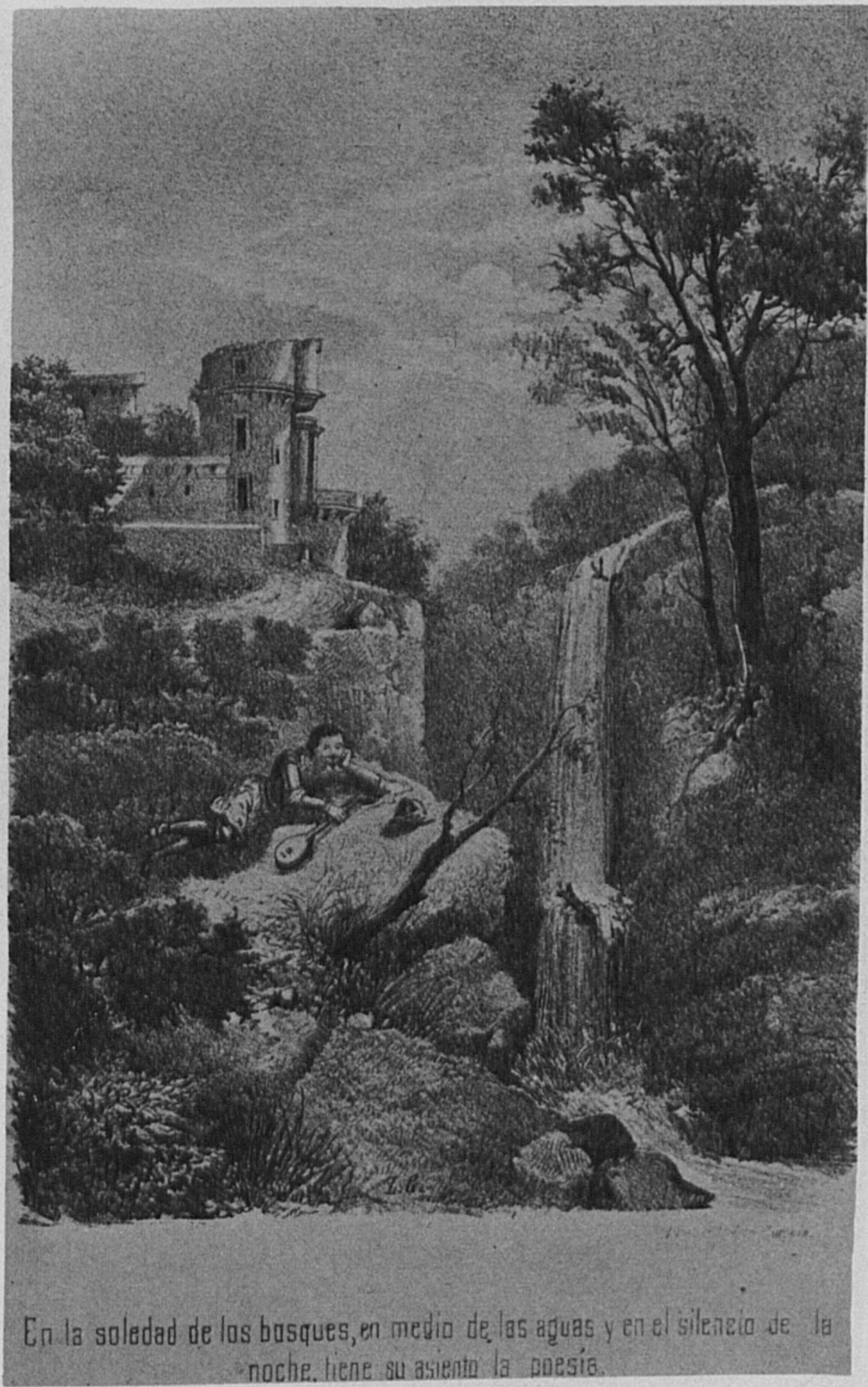

12. En la soledad de los bosques, en medio de las aguas y en el silencio de la noche, tiene su asiento la poesía (El libro de Satanás). 


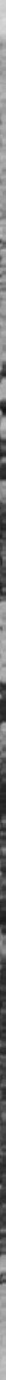

13. A los quince años, el mayor placer se encuentra en una sala de baile (El libro de Satanás). 


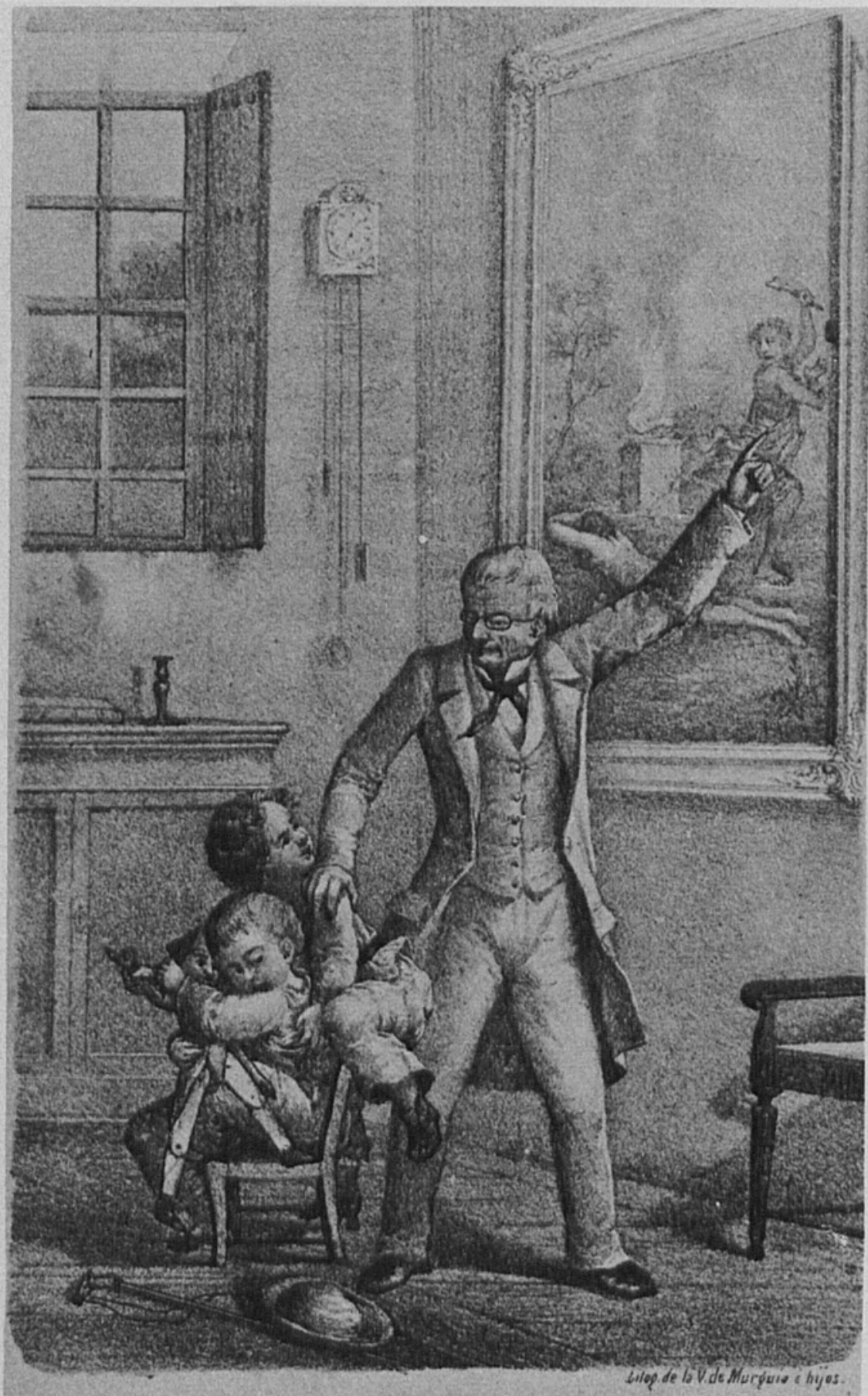

Desde Cain hasta nuestras dias, la envidia no deja de ser. Existe en tados las tiempos y en tadas las edades.

14. Desde Caín hasta nuestros días, la envidia no deja de ser. Existe en todos los tiempos y en todas las edades. La luz en las tinieblas (El libro de Satanás). Segunda parte. 


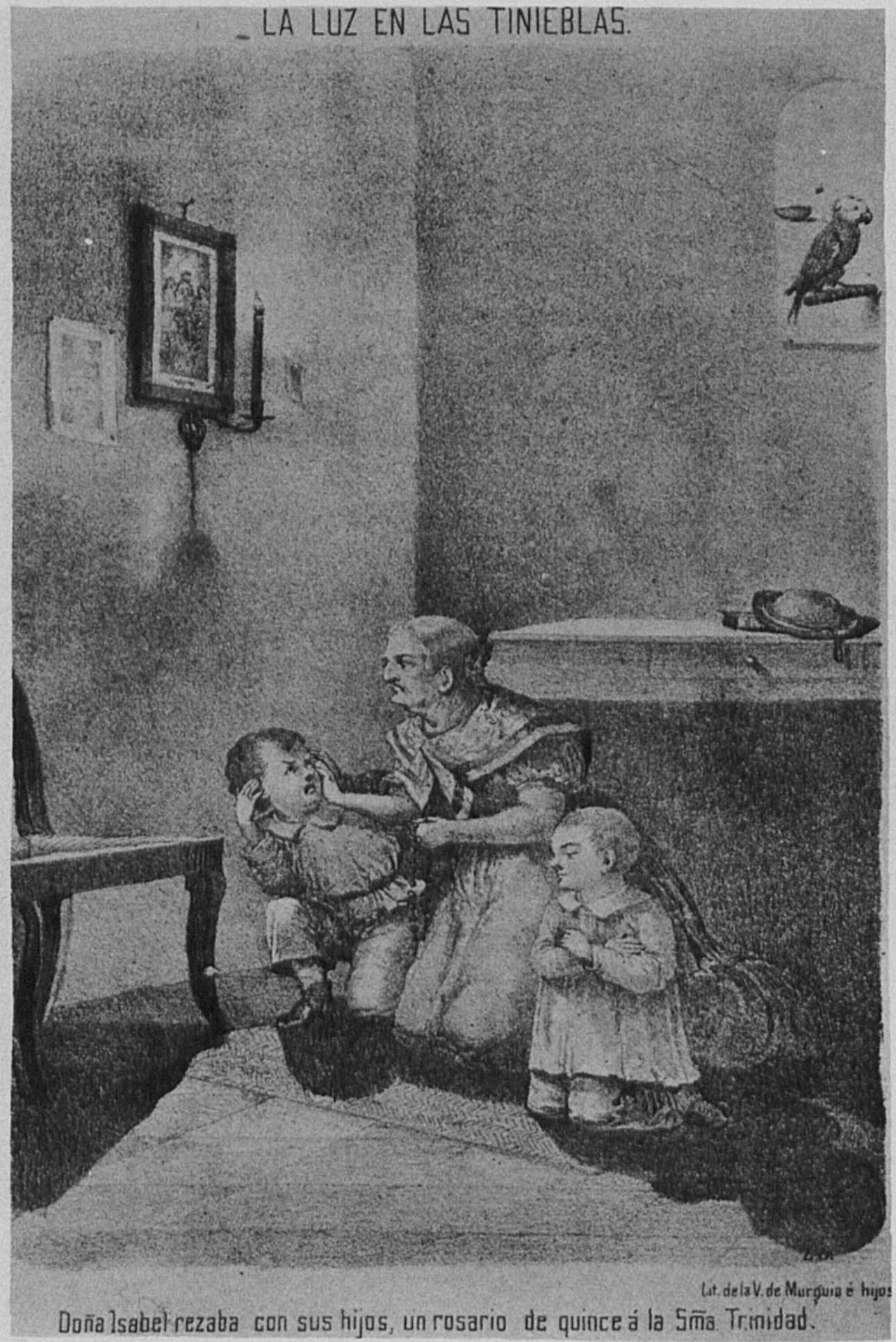

15. Doña Isabel rezaba con sus hijos, un rosario de quince a la Santísima Trinidad. La luz en las tinieblas. 
DOI: http://dx.doi.org/10.22201/iie.18703062e.1976.45.1031

El libro de Satanás.

Seqgunda parte.

\section{LA LUZ EN LAS TINIEBLAS.}


DOI: http://dx.doi.org/10.22201/iie.18703062e.1976.45.1031

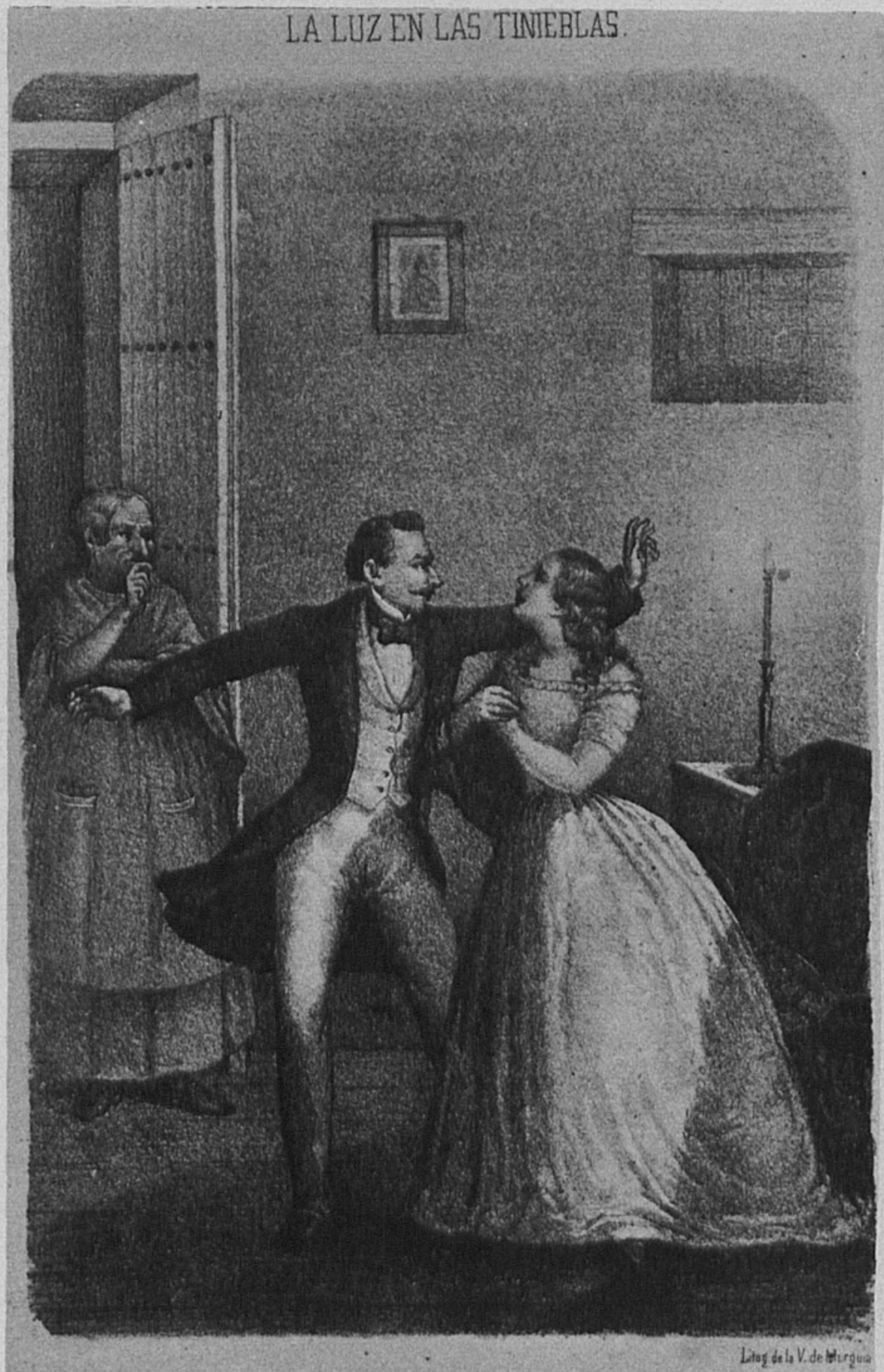

Tú, la prostituta, eres mas d̆rande que las pudorosas hijas de los aristócratas.

17. Tú, la prostituta, eres más grande que las pudorosas hijas de los aristócratas. La luz en las tinieblas. 
DOI: http://dx.doi.org/10.22201/iie.18703062e.1976.45.1031

\section{LA LUZ EN LAS TINEBLAS}

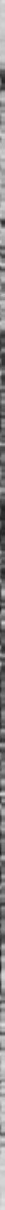

Alfredo atraviesa la plaza del Salta del Añua. 


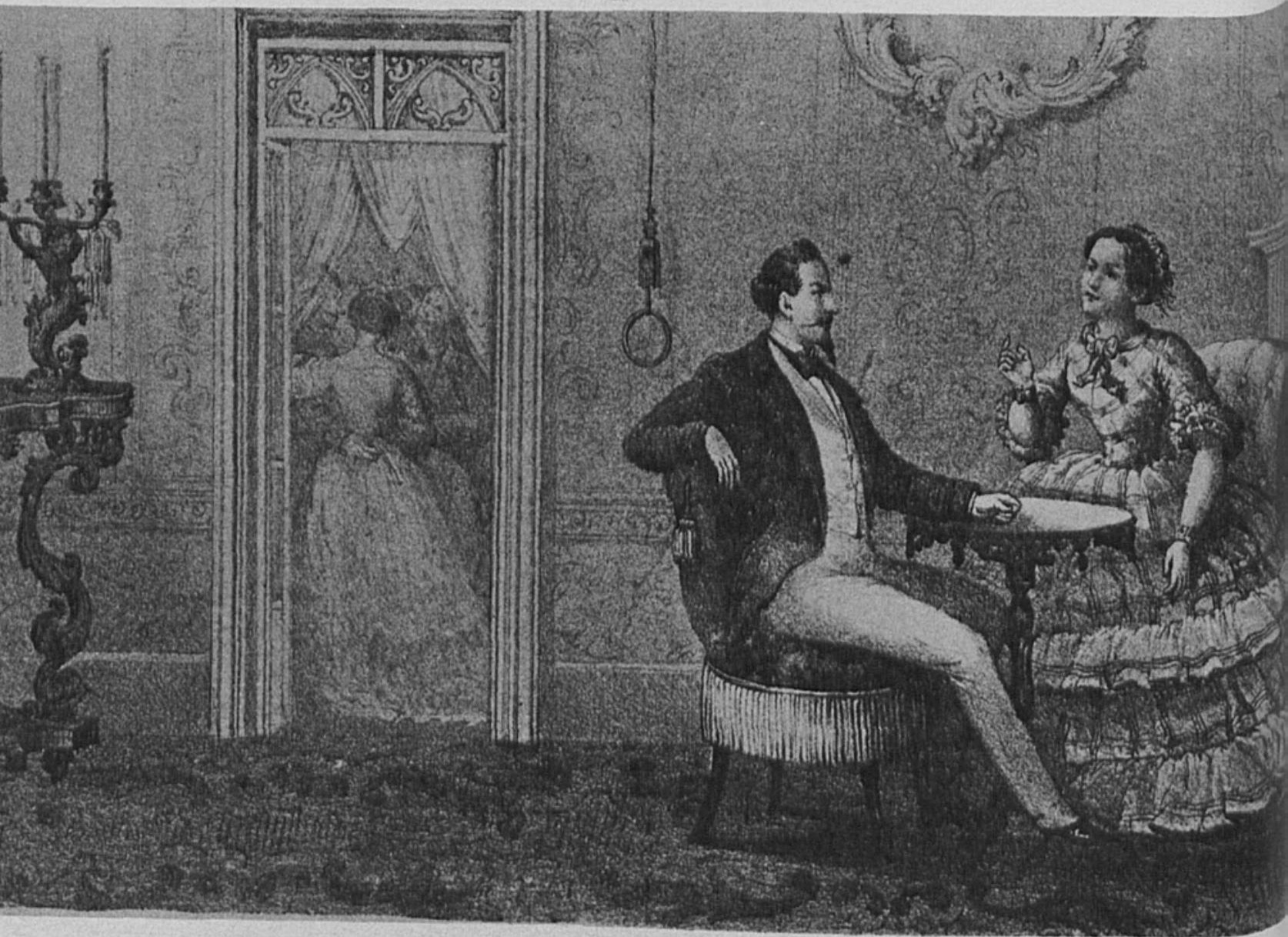

19. Cuántas veces mi madre y yo, pasamos días sin desayunarnos. La luz en las tinieblas. 


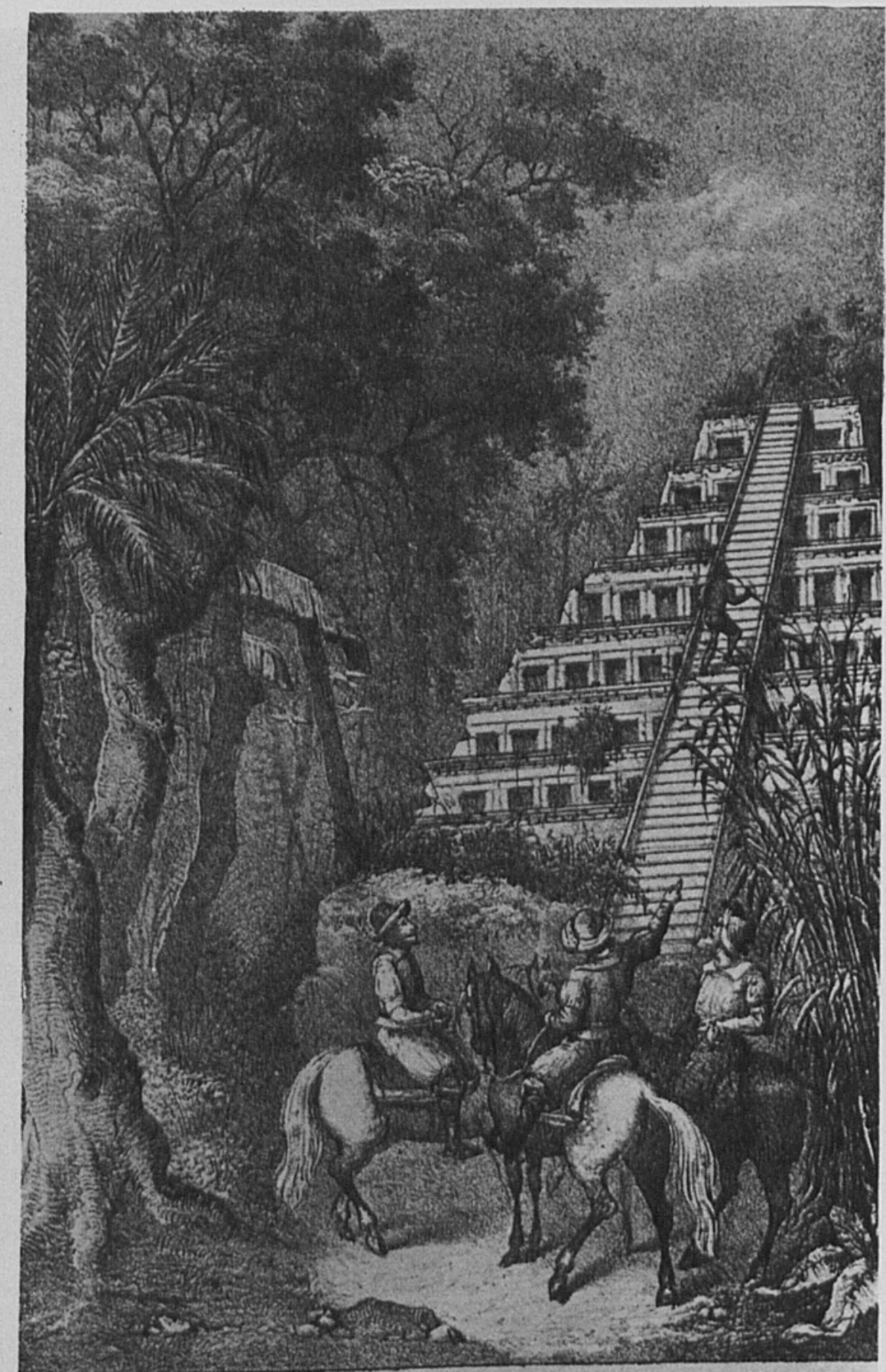

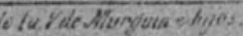

G. Gueves of F) Thin 


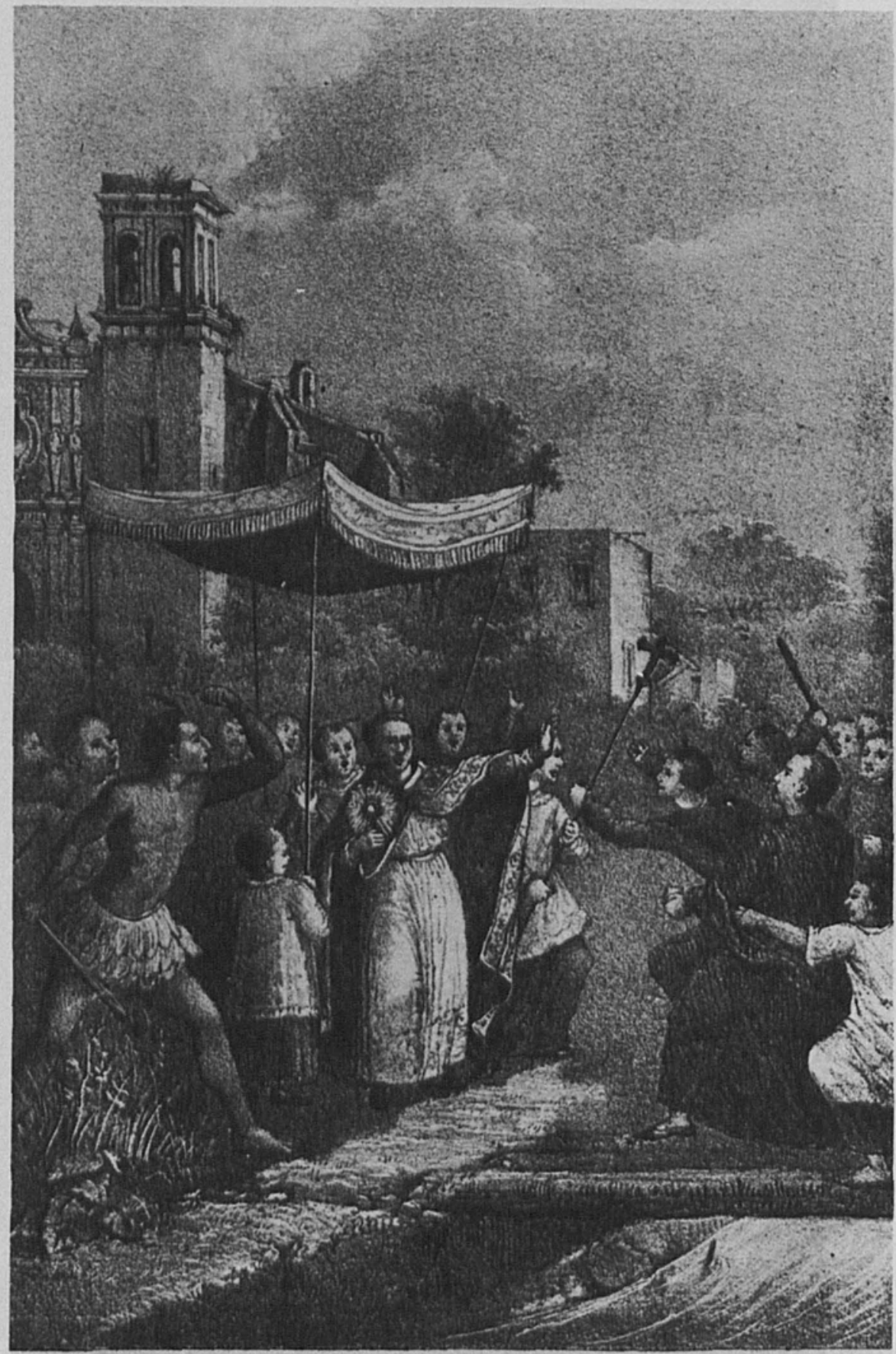

de la V.deMuryuid

L. Gactas d

Procesian. de Santa Maria la Redonda. 


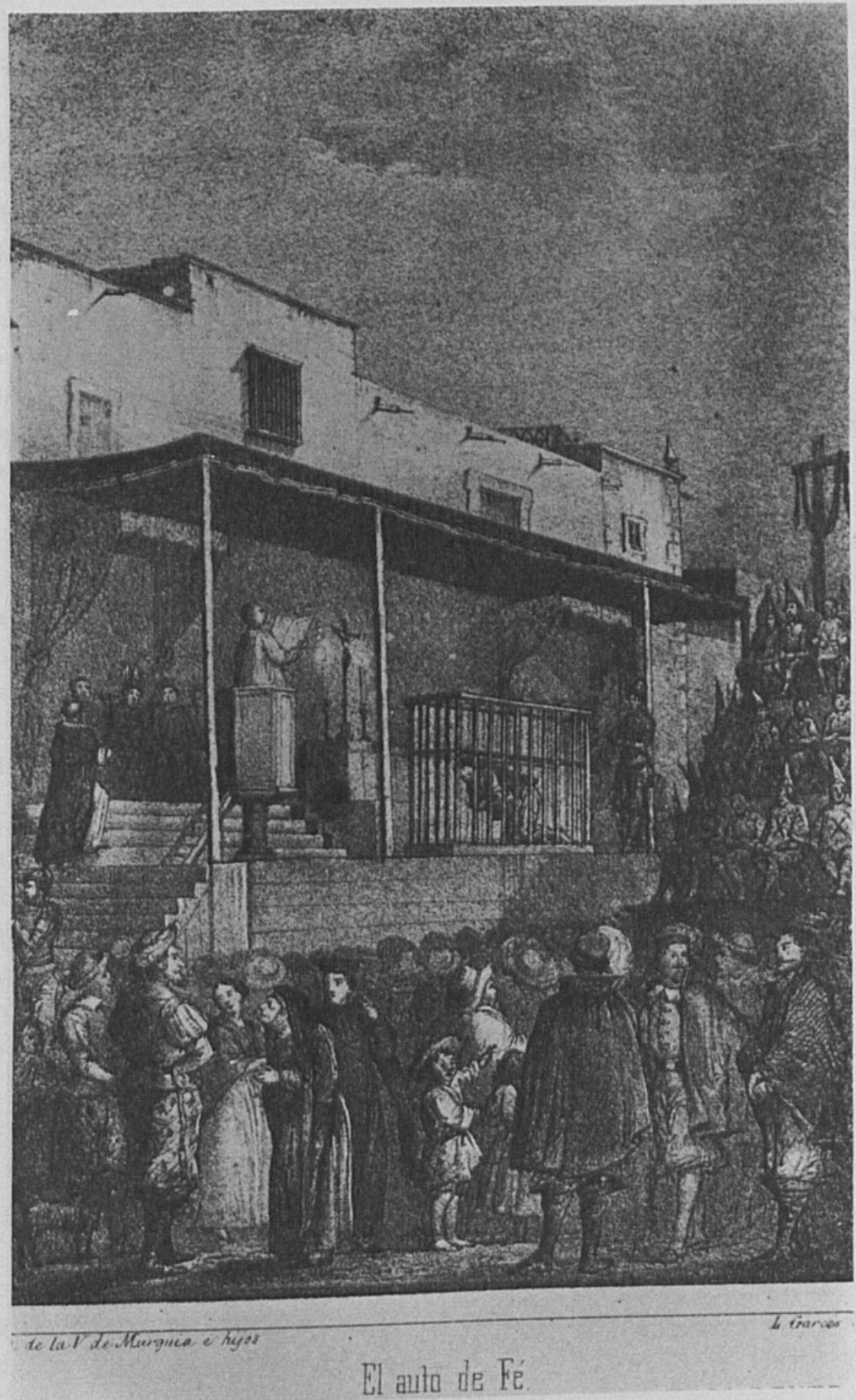

22. El auto de fe. Un hereje y un musulmán. 
DOI: http://dx.doi.org/10.22201/iie.18703062e.1976.45.1031

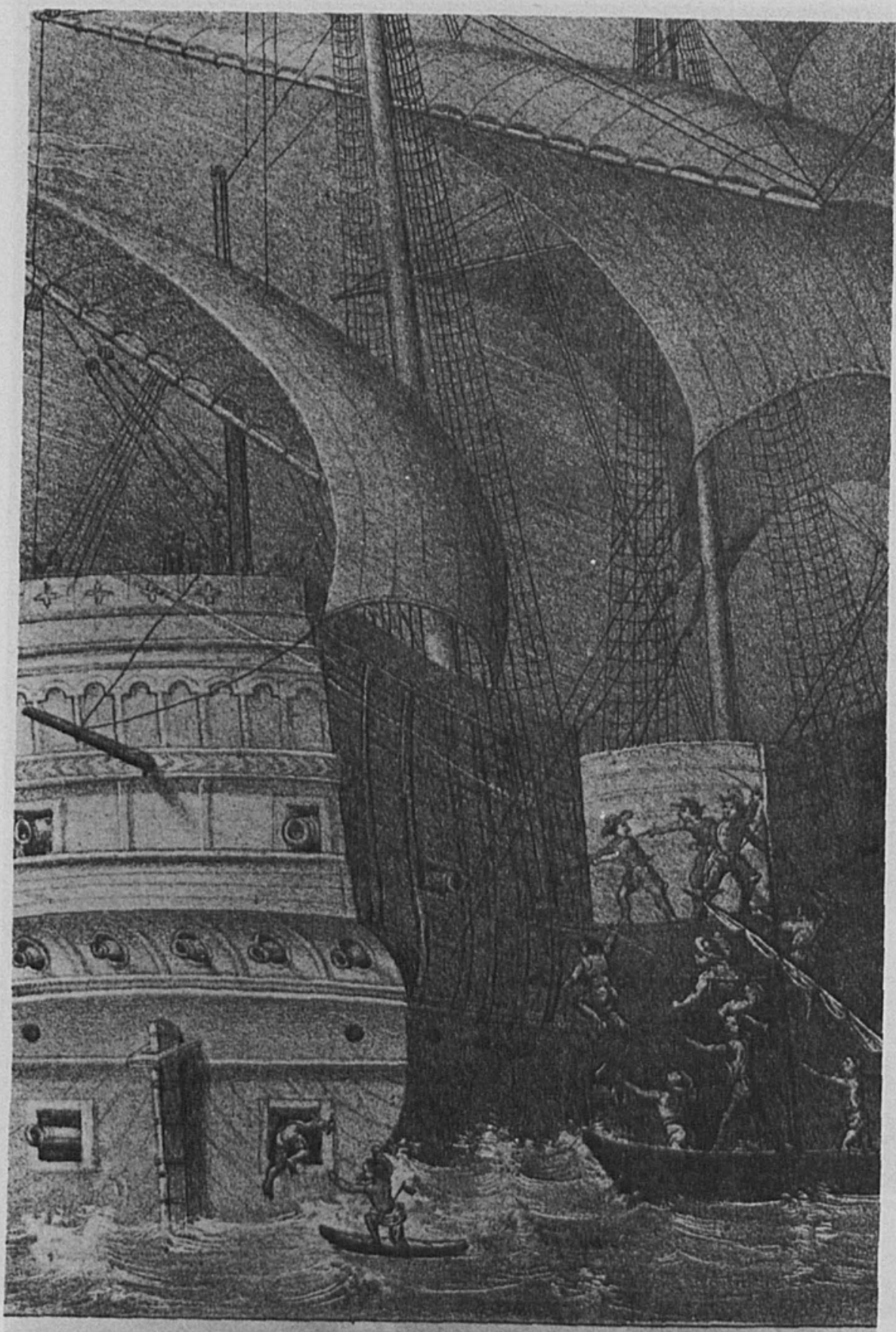

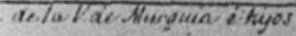

E. Gaves dit

El abordage. 
de dos estípites contrapuestos, a los que Manuel González Galván llama modalidad "losángica". 7 No sólo el fuste losángico, sino también el óculo mixtilíneo -como se ve en el templo- contribuyen a comunicar el carácter a esas iglesias de la agonía barroca dieciochesca. La torre medio derruida de la iglesia, el reloj marcando las seis de la tarde, la hora crepuscular, nos advierten que hasta las regiones y los grandes monumentos perecen. $Y$ no se diga de otros símbolos como del pretérito al presente nos insisten en esta romántica reflexión: Ia remota pirámide más allá del templo, habla del sepulcro de los poderosos faraones y de su deseo de vencer al tiempo y a la muerte. Después la clásica columna rota, como la vida que se trunca, uno de los símbolos que más usó el romanticismo, que pese a la fuerza y gallardía no resiste el paso del tiempo. El árbol seco frente a la columna -símbolo romántico- la vida que se agosta y, sólo puede anidar entre sus mustias ramas Ia sabiduría. Un anciano a un lado de la reja, con cayado de peregrino sugiere la riqueza que se esfuma con el tiempo. De esa reja arranca un estrecho sendero que conduce al sepulcro. Cercana a éste, aunque de pequeña dimensión, pero omnipotente y en primer plano está la clepsidra alada y la guadaña del tiempo que todo lo siega. El jaramago, hierba que crece por doquier entre los escombros, invade los muros de la barda atrial.

11. "La fe. Si tuviereis fe y dijereis a un monte: pásate; el monte se pasará. (San Marcos.)"

Cristo hace hincapié en la virtud y en el poder de la fe. Acompañan al Maestro tres apóstoles y una mujer embelesada por sus palabras abraza a un niño. Un árbol, un caserfo con su palmera y al fondo los montes señalados por el Señor a los que la fe puede trasladar, motivo de la ilustración.

12. "En la soledad de los bosques, en medio de las aguas y en el silencio de la noche, tiene su asiento la poesía."

En esta leyenda que se lee al pie de la estampa y el ditirambo que consagra a la poesía el escritor "Satanás", declara su postura romántica. La poesía, hija del corazón, sublima "la materia vil y despreciable poniéndonos frente a Dios". El poeta, un visionario, es el único al que le es dable penetrar en los arcanos de la vida, de la naturaleza, de los sentimientos, atisbar el porvenir. Alegria reafima su dicho con

7 Esta modalidad del barroco, la estudia González Galván en Del Arte. Homenaje a Justino Fernández, de próxima aparición. 
una copiosa lista de poetas "que al son de su acordada lira predicen los destinos mismos de la humanidad". Añade a estos poetas notables en la literatura universal a los mexicanos Sor Juana Inés de la Cruz, fray Manuel Martínez de Navarrete, Fernando Calderón, Ignacio Rodriguez Galván y a los de su tiempo, entre otros, Juan Díaz Covarrubias, muerto por sus ideas liberales en 1859, Juan Valle, José Rosas, Esther Tapia, Isabel A. Prieto.

Garcés ha ceñido el sentir del autor en esta espléndida escenografía romántica en que se encuentran reunidos los principales elementos del romanticismo: la valoración del pasado en el ambiente medieval, la soledad en donde el poeta -aquí un trovador con su vihuela, y también caballero lleva armadura- abismado en sus ideas, busca la inspiración para cantar recónditos pesares. La naturaleza abandonada a sí misma, en plena libertad, los árboles con las raices de fuera a punto de caerse, los riscos, el arroyuelo que se despeña; las ruinas, el castillo con su torreón destruido como representante del triunfo de "lo natural sobre lo artificial". El nocturno en ese paisaje de ligeras nubes que embozan la luna. El misterio, el silencio, paisaje que viene a ser la proyección espiritual de ese ser solitario y egocentrista, el poeta romántico.

13. "A los quince años, el mayor placer se encuentra en una sala de baile."

El baile y su desenvolvimiento es el tema que toca Alegria, alude a sus inicios en las diversas culturas. Comenta cómo el baile es ocasión para lucir trajes, guantes, peinados, joyas, para abrazar a las mujeres, obtener compromisos de amor, y es causa también de infidelidades, de faltas a la moral, de los duelos. Con todo y sus peligros el baile es uno de los grandes goces y no se puede prescindir de él ya que anima la vida.

Lo asentado por Alegría inspira a Garcés una deliciosa escena costumbrista: el baile casero. El ambiente está recreado con mucho donaire. La alfombra y el tapiz de los muros del salón coinciden en una especie de caracoleo recocó, la nota romántica se acentúa con el cuadro de marco oval, el candil y el macetón de rosas. Un típico cuarteto, y las lindas y jóvenes parejas en movimiento. Ellos con elegante frac, chaleco de piqué blanco, botines "encerados", cabellera rizada como pedía la moda. Ellas con vaporosos trajes de muselina blanca, adornadas con discretas joyas, con guirnaldas de flores en esos peinados de que se ufanaban las conocidas peluquerías y perfumerías la de Pedro Montauriol, la de Enrique A. Escabasse, de la calle de Plateros. 
Mientras los jóvenes disfrutan de los bailes de la época: vals, danza habanera, contradanza, scotisch, polka corrida, el padre sentado en una silla con respaldo de rosas, vigila que nadie se propase, que no haya esos "tocamientos" que escandalizaban a Alegría. En el comedor se encuentran los entusiastas del champagne, el sauterme, el jerez y el oporto, de los pasteles y bizcochos. La mesa cubierta con un amplio mantel, su florero, platos y botellas. Los que brindan son celebrados por uno de los asistentes.

Segunda parte de El libro de Satanás, La luz en las tinieblas. Alegría expone las intenciones de esta segunda parte:

Nos hemos propuesto dar en ella tres pequeñas novelas que sirvan de ejemplo a las doctrinas sentadas en la primera parte de esta misma obra.

Al hacerlo así, no nos guía otro fin, que el no cansar a nuestros lectores con la aridez que caracteriza siempre a toda obra filosófica.

En estas tres novelitas que forman una sola, son la romántica historia de dos jóvenes hermanas, víctimas de un malvado, arrastradas al vicio, una con mejor posición que otra, que al fin se encuentran y se redimen. La enseñanza moral del romanticismo: el villano que recibe el castigo a manos del bueno aquí se cumple. El humanitarismo romántico: la reivindicación de la mujer caída por el amor, explica el título de la novela: Luz en las tinieblas.

Al igual que en la primera parte de El libro de Satanás, en esta segunda no hay filosofía ni valor literario, el interés se encuentra en el testimonio costumbrista. Buen observador, Alegria describe la vida cotidiana de la clase media y baja. Pinta tipos como el modesto empleado público, su mujer, el profesor de idiomas, el huizachero y sus malas artes. Describe los rumbos y las casas donde vive la clase media de pocos posibles, un patio, dos recámaras, una cocina, y un segundo patio o corral, el mobiliario. También las casas de vecindad, morada de la clase baja y los oficios que ésta desempeña, no olvida a los que a diario y a horas fijas entran en el patio de la vecindad, limosneros rezando letanías, los que pregonan frutas, dulces, papas, rebozos, periódicos, novenarios, calendarios, los compradores de hilacha y sebo. Las casas donde vive la clase que está entre la media y la baja, en suma, 
las costumbres del México de mediados de siglo, Luz en las tinieblas, novela de estructura lineal abarca de 1844 a 1859.

Lo importante de esta novela es el costumbrismo y, desde luego, las estampas en que Garcés captó la vida mexicana.

Las litografías van en el siguiente orden y están numeradas aquí del 14 al 19.

14. "Desde Caín hasta nuestros días, la envidia no deja de ser. Existe en todos los tiempos y en todas las edades."

En la litografía el padre -parece un abuelo o un maestro- indica a los dos rollizos chicos que pelean por un juguete el resultado de la envidia en el cuadro de la pared: la muerte de Abel a manos de Caín, celoso porque el humo del sacrificio de su hermano sube al cielo, complace a Dios. Caín huye empuñando el arma homicida, la quijada de burro.

En el cuarto que pertenece a la clase media, hay una silla imperio, los pequeños están sentados en una silla hecha a su escala. Encima de una modesta cómoda hay un libro y un candelero. En la pared un lindo reloj.

El menor defiende su juguete, un soldado con aspecto de marioneta con goznes, el mayor ha tirado su sombrero y la vara con cabeza de caballo, no falta la brida.

15. "Doña Isabel rezaba con sus hijos un misterio de quince a la Sma. Trinidad."

Otra escena costumbrista. Hincados en un petate los dos niños de la estampa anterior rezan el rosario, pero tres son muchos. Uno de ellos es castigado con un tirón de orejas, en tanto que el otro finge devoción. La expresión de la madre es un acierto, así como la de los niños. No descuida Garcés los detalles de los trajes. El ajuar del cuarto lo componen una silla, versión del chipendale mexicano, con asiento de tule torcido, el cuadro de la Trinidad iluminado por una candela y el perico que habia en casi todas las casas con su escudilla para el alimento. Al fondo una mesa con un libro y un sombrerito.

16. "Raquel."

La prostituta que por necesidad mancha su cuerpo, pero conserva sin tacha su alma, al decir de Alegría, es representada como una casta y dulcísima doncella, rodeada de plantas, con un cesta de flores y mirando desde la balaustrada la lejanía. Estampa que trae a las mientes las que 
algunos años atrás ornamentaron Semanarios, Calendarios y Anuarios dedicados a las señoritas mexicanas.

17. "Tú la prostituta, eres más grande que las pudorosas hijas de aristócratas."

El romanticismo se preocupó por los desvalidos, los marginados de la sociedad, la mujer extraviada es defendida vigorosamente ya que es víctima de la hipócrita sociedad que no le permite regenerarse, pero gracias al todopoderoso amor encuentra salvación.

En la litografía, Alfredo declara a Raquel, la prostituta, el amor que la salva y engrandece. Los muebles en la casa de Raquel en el barrio del Niño Perdido, se reducían -dice Alegría- a una mesa de Jocolotl, "media docena de sillas de tule, una estera también de tule, un canapé de tabla, algunas malas estampas y dos no mejores espejos en las paredes". Siguiendo a Alegría, el artista delineó un pobre cuarto: la puerta con tablones claveteados, la mesa cubierta con un paño y encima un candelero, un cuadro en la pared, todo el énfasis lo puso en el desbordamiento de la expresión melodramática y estática de los amantes y la tía-celestina.

18. "Alfredo atraviesa la plaza del Salto del Agua."

La fuente del Salto del Agua, en donde concluía el acueducto de Belén, que desde Chapultepec traía el agua gorda a la capital está observada directamente, aunque deformada un tanto en su realidad, Garcés respetó sus características generales, se distinguen el gran relieve que se haya en el frontis de la fuente, con las armas de la ciudad de México (siglo xviII), el tazón de piedra sostenido por un grupo de niños sobre delfines, aś como las figuras y el tazón que la rematan. El artista también respetó el ambiente urbano que originalmente rodeaba la fuente como es el portal que está a la derecha y que fue destruido. El farol es de un hermoso y funcional diseño.

19. "Cuantas veces mi madre y yo, pasamos días sin desayunarnos."

En una posada de casa rica, Judith dedicada a la misma profesión que su hermana Raquel, pero con más éxito, cuenta a Alfredo su orfandad llena de privaciones, pues a la muerte de su padre fue despojada su madre de la fortuna, motivo por el que no pudo ir a la escuela: el camino de la prostitución fue su único recurso.

Garcés presenta esta confesión en un ambiente de atmósfera romántica, muy bien conseguida, con una textura en general suave, mullida, 
que se manifiesta en el piso alfombrado, el tapiz de los muros, los muebles capitonados, el cordón borlado para llamar, los cortinajes y, desde luego, en el precioso atuendo de la damisela: el peinado con la guirnalda de flores, las pulseras y el lujoso vestido a cuadros, con olanes en la falda tal como dictaba la moda.

Aun en su carácter romántico y añorante en esta litografia el estilo del pasado tiene una presencia anacrónica muy dentro de la época, sobre todo en los dos arquillos góticos bajo el dintel de la puerta y la aparición de factura rococó en varios de los elementos como la consola, el candelabro y el marco del espejo, lo que demuestra que en el siglo xix no había prejuicio que impidiera mezclar viejas reminiscencias medievales con las más cercanas barrocas dieciochescas, una prueba más del desenfado ecléctico romántico.

Otra novela ilustrada por Luis Garcés fue Un hereje y un musulmán. México hace trescientos años. Novela histórica por Natal del Pomar. Imprenta de Luis Inclán, calle de San José el Real, número 7. 1870.

Dentro de la novela histórica de tema colonial está la novela $U n$ hereje y un musulmán, escrita por el abogado, político y científico Pascual Almazán (1813-1886), que usó para esta su única novela el seudónimo de "Natal del Pomar".

La acción de la obra tiene lugar en la Nueva España y va de 1569 a 1574. El asunto es la persecución e intolerancia religiosas. La novela se adoba con amores contrariados, crueldades, intrigas, recursos de la novela de folletín, utilizados por la novela histórica romántica.

Las litografías llevan el siguiente orden (numeradas del 20 al 23).

20. "El Tajin."

Dos viajeros y su criado contemplan un día de fines de 1569 , la pirámide del Tajín, que se encuentra "en una de las hermosas selvas al sur de la demarcación de Papantla", hoy Estado de Veracruz.

Garcés conserva los perfiles principales de la pirámide, pero la dibuja más alta y menos ancha de lo que es en realidad; no reproduce la escalinata ni la alfarda con su diseño de greca, tampoco los pedestales con nichos de la escalera. Se aprecian los nichos que dan nombre a este monumento de la "cuitura totonaca": Pirámide de los nichos.

Un indio aunque fuera de escala sube la pirámide, en tanto que la señala uno de los viajeros. Especialmente el que está a la derecha des- 
cubre un cierto aire quijotesco. Con sentido realista delinea las monturas. La selva que los rodea umbria y nebulosa como es la selva tropical de aquellos rumbos - paisaje tan grato a los románticos- aparece en todo su esplendor y sensualidad: los gigantescos bambúes, los árboles, los plátanos y palmeras, las hermosas orquídeas "hijas del aire" cuelgan de los árboles y entre éstos revolotean los cenzontles y las calandrias.

\section{1. "Procesión de Santa María la Redonda."}

Uno de los acontecimientos que más ruido hicieron en el siglo xvi en la Nueva España fue la procesión del 15 de agosto de 1569 en la que se enfrentaron franciscanos y clérigos.

Los franciscanos acostumbraban anualmente ir de la capilla de San José a la iglesia de Santa María la Redonda para celebrar a la Virgen de Agosto. Formaban la procesión los franciscanos, los legos, los alumnos indígenas bajo la protección de fray Pedro de Gante, llevando grandes cirios encendidos, los neófitos con ramos de flores y los devotos españoles. Al llegar la procesión a la calle de la Acequia una caterva de clérigos que se encontraba al poniente de la zanja, impidió el paso a los frailes conminándolos a que se volvieran a su convento, esta orden encendió los ánimos, la disputa alcanzó tal magnitud que el virrey don Martín Enríquez se vio obligado a enviar tropas para calmar el tumulto.

Éste es el episodio que ilustra imaginativamente Garcés. Al fondo la capilla de San José, y aunque es del xvi, la dibuja como si fuera del XviII. Esta iglesia es la misma, con unos cuantos cambios, que se halla en la litografía de El libro de Satanás: "Todo vive, todo crece..." Esta iglesia con su torre trunca y su fachada barroca debió ser un caro ejemplo para el litógrafo, puesto que la repite sin importarle el anacronismo o la extemporalidad de la misma.

El sacerdote que lleva la custodia va revestido con alba y capa pluvial, vestiduras que ocultan el hábito que contrastaría su carácter frailuno frente a las sotanas negras de los belicosos clérigos que garrote en mano y amenazadores se apostan en el rústico puente de troncos leñosos. El indio que está en primer plano revela el pulcro dibujo del desnudo indigena que marca el espíritu académico clasicista que privaba en el siglo xix y al que sólo por honestidad se le cubre con un faldellín de plumas.

\section{2. "El auto de fe."}

El artista basado en las descripciones del novelista y, seguramente, 
también en otros documentos que a la sazón se publicaban evoca un auto de fe en el siglo XVI, pero esta evocación la hace con gran libertad.

La fábrica contra la que se recarga el tablado era el palacio del Marqués del Valle, hijo de Cortés, la construcción del siglo xvi, sin embargo, no presenta las caracteristicas de la arquitectura civil de esa centuria, puesto que carece de las típicas almenas y de los torreones angulares que la citada mansión debió tener.

El tablado está cubierto por una vela apoyada en ligeros mástiles que permiten ver lo que en él sucede. En medio está el altar con el crucifijo y los cirios, a los lados los sitiales con bordado dosel para el virrey, los oidores y el arzobispo. En el sitial de la izquierda se columbra al primer inquisidor don Pedro Moya de Contreras y a sus "familiares". Una exagerada visión liberal se advierte en la manera de representar al preso de hinojos encerrado en una jaula al que vigila un soldado con alabarda. Un relator o secretario lee las sentencias en un ambón o púlpito. Un dominico - acaso el prior de la orden- sube al tablado. Al fondo, bajo una cruz, los penitentes con coroza y sambenito de dos aspas en escalones circulares decrecientes se apiñan formando un cono humano.

Lo más interesante de esta ilustración es el bullicioso conjunto donde se encuentran representadas las clases sociales novohispanas. Así están en primer plano los espectadores al auto de fe, que en aquellos tiempos se consideraba como una de las "diversiones" más concurridas y gustadas. Niños, gallardos y nobles caballeros suntuosamente ataviados, damas, órdenes religiosas y pueblo. En la litografía una apesadumbrada doncella, amada de uno de los sentenciados por la Inquisición es reconfortada por una dueña con facha de celestina. Un perro anda entre los asistentes, perro que nunca falta en las estampas litográficas del xix en las que se retrata a la muchedumbre mexicana.

23. "E1 abordaje."

El pirata inglés Francis Drake con su barca "La Foca", aborda el galeón español "San Telmo". En esta litografía, el mayor atractivo plástico se halla en la proximidad del enfoque al galeón que convierte al velamen, los mástiles y las jarcias en un intrincado juego de líneas de luces y sombras que produce el efecto de algunos de esos complicados diseños abstractos más cercanos a la sensibilidad moderna.

Bajo este hermoso trazo del dibujo, el abordaje resulta un poco ingenuo, más semeja un solaz de niños que el dramático preámbulo al saqueo sanguinario de los piratas, tal parece que el galeón español se dejara tomar sin presentar resistencia. 
En las litografías de Luis Garcés sobresale el dibujo generalmente correcto ya en el paisaje, en lo arquitectónico, en el mobiliario y en los trajes. Las composiciones son sencillas aunque un tanto manidas, pero, a decir verdad, esto no constituye un defecto, pues es una característica de las composiciones decimonónicas. La atmósfera que logra no muestra contrastes violentos de luz y sombra, sino sucesivos planos difuminados en donde los personajes se sumergen en la textura grumosa que deja el lápiz graso sobre la piedra, tan distinto a la oscuridad incisiva de un grabado al buril. La técnica pulcra y el lápiz graso -reitero- crea ese clima pálido y neblinoso muy acorde con las escenas románticas que ilustra, en las que se advierte que Garcés era hombre de lecturas. Buen observador del ambiente y, sobre todo, del ambiente intimista de su tiempo, Garcés nos ha dejado en sus litografías plásticas descripciones del gusto y de los objetos más apreciados, así como de las modas que en ese entonces imperaban.

Su obra es un indiscutible documento de la vida y las costumbres de su época, interpretados a veces con ternura y otras melancólica o irónicamente, pero siempre con singular gracia y encanto $y$, debe ser considerado por sus calidades junto a la de los celebrados litógrafos mexicanos contemporáneos suyos, entre otros Constantino Escalante, Hesiquio Iriarte, Hipólito Salazar y Santiago Hernández. 